DARIUSZ MATELSKI (Poznań)

\title{
RESTYTUCJA POLONIKÓW Z BIAŁORUSI, UKRAINY I LITWY ZA TRZECIEJ RZECZYPOSPOLITEJ
}

\section{Wstęp}

Odzyskanie przez Polskę suwerenności 12 września 1989 r., gdy ukonstytuował się pierwszy po II wojnie światowej niekomunistyczny rząd na czele $\mathrm{z}$ premierem Tadeuszem Mazowieckim, umożliwiło podjęcie przez archiwistów, bibliotekarzy i muzealników zagadnień związanych $z$ rewindykacją lub repartycją polskich dóbr kultury utraconych w przeszłości. Pierwsze zalecenia $w$ tej sprawie minister spraw zagranicznych Krzysztof Skubiszewski sformułował już w listopadzie 1989 roku (czyli po złożeniu 26 października wizyty w Moskwie i udziale w posiedzeniu Komitetu Ministrów Spraw Zagranicznych Układu Warszawskiego), polecając opracowanie wykazu polskich dóbr kultury w ZSRR, które moga podlegać rewindykacji w ramach polsko-radzieckiego protokołu o współpracy kulturalnej i naukowej ${ }^{1}$.

W październiku 1991 r. powołano do życia Biuro Pełnomocnika Rządu Rzeczypospolitej Polskiej do Spraw Polskiego Dziedzictwa Kulturalnego za Granicą, do którego zadań należy inicjacja i koordynacja działań w zakresie ochrony polskiego dziedzictwa kulturalnego za granicą, a w szczególności: 1) w porozumieniu z MSZ wykonywanie umów międzynarodowych, których strona jest Rzeczpospolita Polska, w zakresie ochrony polskiego dziedzictwa kulturalnego za granicą; 2) prowadzenie ewidencji ruchomych i nieruchomych dóbr kultury związanych z Polską, a znajdujących się za

1 J. Skowronek, Międzynarodowa wspótpraca archiwalna: cele - nadzieje-trudności, „Archeion" 1993, t. XCII, s. 7. 
granica w wyniku grabieży wojennych, zmian w przynależności państwowej niektórych terytoriów oraz nielegalnego wywozu; 3) gromadzenie danych dotyczących okoliczności utracenia ruchomych dóbr kultury i możliwości ich restytucji; 4) organizowanie poszukiwań utraconych dóbr kultury polskiej za granicą i podejmowanie działań restytucyjnych; 5) dokumentowanie poloników o szczególnym znaczeniu dla polskiego dziedzictwa kulturalnego; 6) organizowanie i udzielanie pomocy w celu zabezpieczenia i konserwacji dóbr kultury oraz upamiętniania wybitnych osób lub zdarzeń historycznych związanych z polskim dziedzictwem kulturalnym za granicą; 7) promowanie badań naukowych nad polskim dziedzictwem kulturalnym za granica; 8) informacja i propagowanie wiedzy o polskim dziedzictwie kulturalnym za granicą przez publikacje, wystawy i środki masowego przekazu; 9) opieka i pomoc organizacjom oraz instytucjom emigracyjnym prowadzącym działalność w zakresie nauki, kultury i ochrony polskiego dziedzictwa kulturalnego za granicą, wspieranie muzeów, bibliotek i archiwów; 10) współdziałanie z Naczelną Dyrekcją Archiwów Państwowych w zakresie ochrony i rewindykacji polskich zasobów archiwalnych za granicą ${ }^{2}$. Biurem kierowali: Wojciech Kowalski (do 28 lutego 1994), Tadeusz Polak (do listopada 1997) i Stanisław Żurowski ${ }^{3}$. Jednym z najważniejszych zadań Biura okazało się sporządzenie rejestru strat w dziedzinie dóbr kultury. Jak podał w wywiadzie dla „Polityki" Tadeusz Polak:

„Stała się rzecz niewytłumaczalna: od zakończenia wojny minęło 50 lat, a my wciąż nie posiadamy pełnego rejestru strat, jakie poniosła nasza kultura. Nie odtworzyliśmy zaginionej dokumentacji ani spisów muzealnych, nie zebraliśmy fotografii, oświadczeń ludzi, które dziś pozwalałyby udowodnić, że Polska jest właścicielem zbioru dzieł czy obrazu przechowywanego w obcych muzeach. Że to było nasze. Wiele cennych informacji o naszych zrabowanych zbiorach jest dziś prawie nie do odtworzenia, ale od ponad trzech lat biuro, którym kieruję, prowadzi rejestr strat. W komputerach mamy ponad 40 tys. udokumentowanych, zaginionych dzieł sztuki. Wiemy skąd je zabrano. Do końca niemal rozpracowaną mamy już dziś sprawę ksią-

2 „Cenne - Bezcenne - Utracone”, nr 1, luty 1997, s. 15; I. Danis, Dziatalność Petnomocnika Rzadu ds. Polskiego Dziedzictwa Kulturalnego za Granica, w: Katalog utraconych dziet sztuki ( Cenne - Bezcenne - Utracone” - wydanie specjalne), Warszawa 2000, s. $7-10$.

3 J. Miler, Wspótpraca Biura Petnomocnika Rzadu ds. Polskiego Dziedzictwa Kulturalnego za Granica $z$ Biatorusia, Litwa $i$ Ukraina, "Przegląd Wschodni” 1999, t. VI, z. 1 (21), s. 27. 
$\dot{z ̇ e k}^{4}$. Nasze straty sięgają 22 milionów egzemplarzy ${ }^{5}$. Wszystkich tytułów oczywiście nie znamy, ale wiemy, które biblioteki i księgozbiory zostały zrabowane. Został wydany katalog strat książki. Trzeba też pamiętać, że książki były nie tylko wywożone, były też niszczone specjalnie, żeby zniszczyć słowo polskie. Te praktyki dotyczą wschodu i zachodu" 6 .

W latach 1992-97 do programu komputerowego danych wprowadzono ponad 50 tys. zaginionych dzieł sztuki - w większości możliwych do zidentyfikowania na podstawie opisu lub załączonej fotografii. Stanowi to jednak nadal znikomy procent zidentyfikowanych strat, albowiem tylko dla Polski centralnej (tj. dziewięciu powojennych województw, bez ziem utraconych i uzyskanych) straty wynoszą (według danych z 1955 r.) 516 tys. pojedynczych dzieł sztuki 7. Ponadto Biuro Pełnomocnika w 1992 r. rozpoczęło prace nad rejestracją strat bibliotek w granicach z 1945 r. W ciągu trzech lat zgromadzona została baza źródłowa $z$ opisem ponad 40 tys. bibliotek zburzonych lub zdewastowanych w czasie II wojny światowej oraz ponad 5 tys. bibliotek pozostałych na dawnych Kresach Wschodnich Drugiej Rzeczypospoli-

4 Zgromadzona baza źródłowa liczyła wówczas około 40 tys. bibliotek zburzonych lub zdewastowanych w czasie wojny oraz około 5 tys. pozostałych na dawnych ziemiach wschodnich. Zob. Dziatalność Biura Petnomocnika Rzadu ds. Polskiego Dziedzictwa Kulturalnego za Granica, „Cenne - Bezcenne - Utracone”, nr 4, sierpień 1997, s. 3.

5 Dane te nie ujmowały jednak Kresów Wschodnich II RP, utraconych w $1944 \mathrm{r}$. (por.: Straty bibliotek $w$ czasie II wojny światowej w granicach Polski z $1945 \mathrm{r}$. Wstępny raport o stanie wiedzy, pod red. A. Mężyńskiego, Warszawa 1994, część 1-3). Natomiast na podstawie nowszych badań wiadomo, iz w 1939 r. zasoby bibliotek instytucjonalnych i księgozbiorów prywatnych przekroczyły $50 \mathrm{mln}$ jednostek, z czego około $70 \%$, czyli $35 \mathrm{mln}$, przepadło w czasie II wojny światowej. Zob. B. Bieńkowska, Straty bibliotek. Czy wszystkie bezpowrotne?, „Cenne - Bezcenne - Utracone”, nr 6, grudzień 1997, s. 5.

6 J. Wilczak, Wciaż szukamy. Rozmowa z prof. Tadeuszem Polakiem, wiceministrem kultury i sztuki, petnomocnikiem ds. polskiego dziedzictwa kulturalnego za granica, „Polityka”, nr 50 (2015) z 16 grudnia 1995, s. 52-53. W 1998 r. Biuro Pełnomocnika opublikowało cztery bezcenne opracowania: 1) Straty wojenne. Malarstwo polskie. Obrazy olejne, pastele, akwarele utracone w latach 1939-1945, oprac. A. Tyczyńska i K. Znojewska (z Muzeum Narodowego w Warszawie), Warszawa 1998; 2) Zabytki dawnego województwa stanistawowskiego. Wykaz z lat 1921-1939, pod red. R. Brykowskiego i G. Ruszczyk (z Instytutu Sztuki PAN), Warszawa 1998; 3) Monumenta variis Radivillorum. Wyposazenie zamku nieświeskiego w świetle źródet archiwalnych. Część I: XVI-XVII w., oprac. T. Bernatowicz (z Uniwersytetu Warszawskiego), Warszawa 1998; 4) Biblioteki na wschodnich ziemiach II Rzeczypospolitej. Informator, pod red. B. Bieńkowskiej, Warszawa 1998.

7 Zob.: Rejestracja strat wojennych (1939-45) w dziedzinie dziet sztuki. Dziatalność Biura Petnomocnika Rzadu ds. Polskiego Dziedzictwa Kulturalnego za Granica, "CenneBezcenne - Utracone", nr 2, kwiecień 1997, s. 16-17. Por. także: J. Świerczyński, Katalog skradzionych i zaginionych dóbr kultury, Warszawa 1988. 
tej ${ }^{8}$. Natomiast Ośrodek Ochrony Zbiorów Publicznych opublikował na płytach CD Katalog skradzionych i zaginionych dóbr kultury 1939-1999, jednak nie wyposażył go w informacje dotyczące właścicieli utraconych dzieł sztuki ${ }^{9}$.

W odniesieniu do archiwaliów, prawnie zagadnienie restytucji uregulowała uchwalona jeszcze w czasach PRL ustawa z 14 lipca 1983 r. o narodowym zasobie archiwalnym i archiwach ${ }^{10}$, powierzając to zadanie Naczelnej Dyrekcji Archiwów Państwowych. Realizowali je kolejni naczelni dyrektorzy Archiwów Państwowych RP: Marian Wojciechowski i Jerzy Skowronek (od 1 stycznia 1993), a od 1 września 1996 r. pracami tymi kieruje Daria Nałęcz.

Natomiast Ministerstwo Edukacji Narodowej w 1998 r. powołało do życia Radę Dziedzictwa Archiwalnego, na której czele stanął Ryszard Kaczorowski - ostatni prezydent RP na uchodźstwie. Jej zadaniem jest zbieranie i udzielanie informacji, ochrona, udzielanie pomocy fachowej i finansowej przy zabezpieczaniu polskich dóbr kultury, a dopiero następnie ich ewentualna restytucja. Ustalono wówczas zasady postępowania Rady, które zakładały, iż: 1) zabezpieczenie zbioru przed zniszczeniem lub zaginięciem ważniejsze jest od pozyskania zbioru dla jednego $z$ wielkich zbiorów publicznych; 2) pomoc adresowana będzie do wszystkich, bez względu na ich związki organizacyjne czy też powiązania personalne $z$ Radą lub innymi instytucjami; 3) zagwarantowane będzie poszanowanie autonomii i praw każdej instytucji

8 Zob. U. Paszkiewicz, Rękopiśmienne inwentarze i katalogi bibliotek z ziem wschodnich Rzeczypospolitej (spis za lata 1553-1939), Warszawa 1996; taż, Inwentarze i katalogi bibliotek z ziem wschodnich Rzeczypospolitej do 1939 r. Suplement 1, Warszawa 2000; J. Szymański, Działalność Biura Pełnomocnika Rzqdu ds. Polskiego Dziedzictwa Kulturalnego za Granica, „Cenne - Bezcenne - Utracone”, nr 3 (9), czerwiec 1998, s. 3.

9 Zob.: www.icons.pl; P. Szlachetko, Elektroniczny przewodnik, „Cenne - Bezcenne - Utracone", nr 5 (23), październik 2000, s. 13; P. Ogrodzki, Katalog skradzionych i zaginionych dóbr kultury dostępny na płytach $C D$, „Cenne - Bezcenne - Utracone”, nr 1 (19), luty 2000, s. 15; tenże, Komputerowe bazy danych o zaginionych dziełach sztuki, w: Katalog utraconych dziet sztuki..., s. 16-21. Jest to sprawa niezmiernie ważna, albowiem w latach Trzeciej Rzeczypospolitej odnotowujemy gwałtowny wzrost przestępstw przeciwko dobrom kultury. Kiedy w latach 1946- 1989 odnotowano około 12 tys. tego typu przestępstw, to tylko w latach 1989-1998 było ich aż 14 tys. Lawinowo wzrósł również przemyt dzieł sztuki poza granice kraju. Zob. P. Ogrodzki, Raport w sprawie zagrożeń dóbr kultury, Część I, „Cenne - Bezcenne - Utracone”, nr 4 (22), sierpień 2000, s. 3 i 15. Najbardziej dotkliwą stratą w polskich zbiorach muzealnych była kradzież obrazu „Wybrzeże w Pourville" Claude'a Oskara Moneta (namalowany w 1882 r.), dokonana 19 września 2000 r. w Muzeum Narodowym w Poznaniu. „Cenne - Bezcenne - Utracone”, nr 5 (23), październik 2000, s. 2.

10 Dzieje archiwistyki polskiej. Wybór źródet, wstęp S. Sierpowski i D. Matelski, wybór i oprac. D. Matelski, Poznań 1988, t. I, s. 204-222 (dok. 43). 
oraz osoby prywatnej, która zwróci się do Rady z chęcią współpracy lub z prośbą o pomoc, a także poszanowanie suwerenności decyzji tych instytucji; 4) Rada będzie składała okresowe sprawozdania ze swojej działalności ${ }^{11}$. Inauguracyjne posiedzenie Rady odbyło się 20 maja 1999 r. w Warszawie. Członkami Rady zostali: Janusz Morkowski - wiceprzewodniczący (dyrektor Muzeum w Rapperswilu), Eugenia Maresch - sekretarz (z Biblioteki Polskiej w Londynie) oraz Janusz Cisek (były dyrektor Instytutu Józefa Piłsudskiego w Nowym Jorku), Ryszard Dembiński (prezes Instytutu Polskiego i Muzeum im. gen. Sikorskiego w Londynie), bp Jan Kopiec (sufragan opolski, delegat Konferencji Episkopatu Polski), Daria Nałęcz (naczelny dyrektor Archiwów Państwowych), Andrzej Stelmachowski (prezes Stowarzyszenia „Wspólnota Polska”), Andrzej Suchcitz (kierownik Archiwum Instytutu Polskiego i Muzeum im. gen. Sikorskiego w Londynie) i Czesław Zychowicz (prezes Stowarzyszenia Polskich Kombatantów - Federacja Światowa w Londynie). Sekretariat Rady znajduje się w gmachu Naczelnej Dyrekcji Archiwów Państwowych w Warszawie ${ }^{12}$.

Jednym z najważniejszych wówczas zadań zarówno dla dyplomacji jak i najwyższych władz polskich było wznowienie negocjacji rewindykacyjnych ze Związkiem Radzieckim. W kwietniu 1990 r. podczas wizyty prezydenta RP Wojciecha Jaruzelskiego w Moskwie - po poruszeniu z Michaiłem Gorbaczowem zagadnień związanych z mordem katyńskim - dokonano symbolicznego przekazania stronie polskiej dwóch teczek materiałów archiwalnych NKWD dotyczących mordu na jeńcach - oficerach polskich, dokonanego wiosną 1940 r. w Katyniu. Wówczas - w trosce o prawdę o Katyniu - zapowiedziano rewindykację innych poloników z ZSRR (głównie ze Lwowa) ${ }^{13}$.

Rozpad ZSRR w 1991 r. i powstanie na jego gruzach państw narodowych postawiło na porządku dziennym zagadnienie dalszej rewindykacji materiałów archiwalnych dotyczących nie tylko okresu II wojny światowej, ale także ziem wchodzacych w skład Rzeczypospolitej w wiekach XVI-XVIII. Chodzi tutaj zwłaszcza o udostępnienie przechowywanej w Moskwie Metryki Litewskiej. Strona polska nie domaga się jej przekazania do Warszawy (skąd

11 Rada Dziedzictwa Narodowego, Warszawa 2001, s. 8.

12 B. Woszczyński, Z obrad Rady Archiwalnej, „Archiwista Polski” 2000, R. V, nr 1 (17), s. 68; Rada Dziedzictwa Narodowego..., s. 10-11.

13 Kontynuowane były w 1990 r. kwerendy archiwalne we Lwowie w zespołach Gubernium i Namiestnictwa Galicyjskiego oraz dalsze mikrofilmowanie tych przekazów przez stronę ukraińską. D. Rocka, Sprawozdanie z działalności państwowej służby archiwalnej w roku 1990, „Archeion” 1994, t. XCIII, s. 318. 
została w 1795 r. wywieziona do Rosji), ponieważ zgodnie z zasadą pertynencji powinna ona znajdować się w Wilnie, Mińsku lub Kijowie (które posiadają mikrofilmy tego zespołu) ${ }^{14}$, lecz zabiega wykonanie mikrofilmów lub hologramów.

Uzyskanie niepodległego bytu przez Białoruś, Litwę i Ukrainę uaktualniło także problem archiwaliów wytworzonych przez administrację II Rzeczypospolitej na terenach, które zostały utracone na rzecz ZSRR w roku 1944. Dotyczy to zwłaszcza odpisów ksiąg wieczystych, których brak uniemożliwia weryfikację wniosków odszkodowawczych za utracone „mienie zabużańskie".

\section{Polsko-białoruskie negocjacje restytucyjne}

W czerwcu 1992 r. do Mińska przybyła dwuosobowa delegacja NDAP (Edward Frącki i Bolesław Woszczyński) w celu przygotowania polsko-białoruskiego porozumienia w sprawach archiwalnych. Umożliwiło to podpisanie już 29 września tegoż roku w Warszawie przez Mariana Wojciechowskiego (naczelny dyrektor) i Aleksandra M. Michalaczenkę (przewodniczący Głównego Zarządu) Porozumienia o wspótpracy między Naczelna Dyrekcja Archiwów Państwowych a Gtównym Zarzqdem Archiwów przy Radzie Ministrów Biatorusi. Podpisano też Protokół techniczny, który regulował zasady wymiany bezdewizowej archiwistów, mikrofilmowania archiwaliów oraz wymiany odbitek reprograficznych ${ }^{15}$. W punkcie 4 Porozumienia zapisano, że:

„Strony w celu dokonania scalenia zespołów archiwalnych powołaja grupę ekspertów, która ustali konkretne formy tego scalenia. Dokumentacja archiwalna stanowiąca własność drugiej Strony powinna być bezzwłocznie zwrócona państwu lub prawowitemu właścicielowi" 16

14 O dziejach archiwum państwowego Wielkiego Księstwa Litewskiego więcej szczegółów znajdzie czytelnik w pracach: Grimsted Patricia Kennedy, The Lithuanian Metrica in Moscow and Warsaw. Reconstructing the Archives of the Grand Duchy of Lithuania, Cambridge-Massachusetts 1984; Issledowania po istorii Litowskoj Metriki. Sbornik naućnych trudow. Część 1-2, Moskwa 1989; Lietuvos Metrika metu tyrinejimai, Vilnius 1992 (jest to zbiór referatów wygłoszonych w 1988 r. na konferencji w Wilnie).

15 B. Woszczyński, Wspótpraca archiwalna z Rosja i Białorusia, „Archeion” 1993, t. XCI, s. $258-259$.

16 W. Stępniak, Sprawy archiwów w stosunkach Polski z jej wschodnimi sasiadami, „Archiwista” 1995, r. XXIX, nr 89, s. 49; B. Woszczyński, Losy archiwaliów polskich na byłych ziemiach wschodnich RP, w: Archiwa polskie wobec wyzwań XXI wieku. Pamiętnik III Powszechnego Zjazdu Archiwistów Polskich. Toruń 2-4 wrzesień 1997, pod red. D. Nałęcz, Radom 1997, t. 1, s. 70. 
Uzgodniono także zagadnienia związane z przekazywaniem bieżących informacji o posiadanym zasobie między obu służbami archiwalnymi, których efektem powinno być opublikowanie wspólnego informatora o zasobach archiwów obu państw. Postanowiono przystąpić także do prac nad wspólną edycją źródeł przechowywanych w archiwach centralnych w Warszawie i Mińsku, do dziejów Polski i Białorusi ${ }^{17}$. Już w 1992 r. przybyła do Mińska delegacja Wojskowej Komisji Archiwalnej, która wyselekcjonowała 420 teczek akt z lat 1919-1921 i 1939-1945, z których sporządzono około 5 tys. kserokopii ${ }^{18}$.

W 1993 r. rozpoczęto wymianę mikrofilmów, uzyskując dla AGAD zbiory Radziwiłłów ${ }^{19}$. Natomiast we wrześniu tegoż roku w ramach współpracy między Archiwum Narodowym Republiki Białorusi w Mińsku a Archiwum Głównym Akt Dawnych w Warszawie, Władysław Stępniak zaproponował rekonstrukcję (poprzez opracowanie przewodnika oraz reprografowanie materiałów) centralnych archiwów państwowych Wielkiego Księstwa Litewskiego i Rzeczypospolitej po roku 1569. Archiwiści białoruscy wykazali ogromne zainteresowanie tą formą współpracy ${ }^{20}$.

Ponadto na terytorium Białorusi znajduje się w archiwach obwodowych (obłastnych), sporo dokumentów ewakuowanych tam w pierwszych dniach września 1939 r. z terenowych archiwów w Polsce zachodniej i centralnej. Są to materiały dotyczące oświaty, funkcjonowania administracji państwowej (łącznie z więziennictwem) oraz wyborów parlamentarnych i samorządowych. W Archiwum Muzeum Literatury i Sztuki w Grodnie przechowywane są materiały związane z Adamem Mickiewiczem i Elizą Orzeszkową. Znajdują się tam także filmy dokumentalne, m.in. Legioniści w Grodnie (w 1920 r.) i Wybory deputatów w Biatymstoku (1920 r.). Ponadto wartościową dokumentację dla lat 1918-1939 posiada Archiwum Obwodowe w Brześciu ${ }^{21}$.

17 B. Woszczyński, Wspótpraca archiwalna z Rosja i Biatorusia..., s. 259.

18 R. Masłowski, Informacja o wybranych dokumentach pozyskanych w archiwach Litwy i Białorusi w ramach prac Wojskowej Komisji Archiwalnej, „Białostocczyzna” 1997, nr $2(46)$, s. 128.

19 J. Skowronek, Międzynarodowa wspótpraca archiwalna..., s. 20.

20 W. Stępniak, Konferencja naukowa w Mińsku, „Archeion” 1995, t. XCIV, s. 251-253. Zob. także: M. Kulecki, Pobyt stużbowy w Mińsku, „Archeion” 1994, t. XCIII, s. 371-374 (tam wykaz zespołów zawierających polonika); E. Szymczuk, Kwerenda archiwaliów w Mińsku, „Archeion” 1997, t. XCVII, s. 408-412.

21 J. Skowronek, Międzynarodowa wspótpraca archiwalna.., s. 20. 
W dniu 18 listopada 1992 r. zawarta została między rządami obu państw Deklaracja o wspótpracy kulturalnej, naukowej $i$ edukacyjnej, a 25 marca 1995 r. podpisano Porozumienie między Rzadem Rzeczypospolitej Polskiej a Rzqdem Republiki Biatoruś o wspótpracy $w$ dziedzinie ochrony dziedzictwa kulturalnego ${ }^{22}$. Oceniając współdziałanie polsko-białoruskie w ochronie wspólnego dziedzictwa kulturalnego w latach 1992-1995, Tadeusz Polak (Pełnomocnik Rządu RP ds. Polskiego Dziedzictwa Kulturalnego za Granicą) stwierdził, że: „Dobrze układa się współpraca z Białorusią: pomagamy w ratowaniu zamku w Krewie i Nowogródku, szlaku mickiewiczowskiego. W Nieświeżu powołaliśmy wspólnie Akademię Nieświeską, szkolimy tam służby konserwatorskie. Ratujemy. Ale [...] województwo nowogródzkie miało ponad 400 dworków. A dziś zostało kilkanaście" 23.

Nawet po dojściu do władzy Aleksandra Łukaszenki - jako prezydenta Białorusi - gdy polityczne kontakty polsko-białoruskie uległy ochłodzeniu, to współpraca archiwistów, bibliotekarzy i muzealników obu krajów była nadal aktywna i badacze białoruscy licznie uczestniczyli we wszystkich organizowanych konferencjach, regularnie odwiedzając Polskę i dzieląc się z uczonymi polskimi swoimi postępami w badaniach naukowych. Tym kontaktom ze strony białoruskiej patronowała Emma Dawydowa, naczelnik Wydziału Komitetu do Spraw Archiwów i Dokumentacji Białorusi ${ }^{24}$.

Jednak międzypaństwowe rozmowy rewindykacyjne utknęły w martwym punkcie. Na mocy wcześniejszych porozumień powołano wprawdzie w 1997 r. Komisję Konsultacyjną Polsko-Białoruską ds. Dziedzictwa Kulturalnego, której przewodniczącym został prof. Andrzej Ciechanowski. Na czele delegacji polskiej stanął Stanisław Żurowski (Pełnomocnik Rządu RP ds. Polskiego Dziedzictwa Kulturalnego za Granicą), a delegacji białoruskiej - Dmitryj S. Bubnowski (Pełnomocnik Rządu Republiki Białoruś, Przewodniczący Państwowej Inspekcji ds. Ochrony Dziedzictwa Kulturalnego) ${ }^{25}$.

22 J. Miler, Wspótpraca Biura Petnomocnika Rzadu..., s. 27-28

23 J. Wilczak, Wciaz szukamy..., s. 53.

24 B. Woszczyński, Międzynarodowa konferencja archiwalna w Puławach, „Archeion” 1997, t. XCVII, s. 351.

25 W skład Komisji ze strony polskiej weszli: dr Tadeusz Bernatowicz (Instytut Historii Sztuki Uniwersytetu Warszawskiego), dr Andrzej Biernat (Naczelna Dyrekcja Archiwów Państwowych), dr Zoja Jaroszewicz-Pieresławcew (Zakład Bibliotekoznawstwa Uniwersytetu Warmińsko-Mazurskiego), dr Maria Kałamajska-Saeed (Instytut Sztuki PAN) i dr Andrzej Michałowski (Ośrodek Ochrony Zabytkowego Krajobrazu). Zob. J. Miler, Wspótpraca Biura Petnomocnika Rzadu..., s. 27-28 i 30. 
Lecz na ty m się skończyło ${ }^{26}$. Równolegle do negocjacji restytucy jnych trwały zabiegi o wyjaśnienie okoliczności mordu dokonanego przez NKWD na Polakach w Witebsku w przededniu ewakuacji przed wojskami niemieckimi. Ponadto na przełomie lat 1939-1940 prawdopodobnie zginęło tam około tysiąca polskich oficerów aresztowanych przez NKWD po napadzie ZSRR na Polskę ${ }^{27}$.

Równocześnie Białorusini rozpoczęli samodzielne studia nad Metryka Litewska, które są od 2001 r. publikowane w czasopiśmie "Metriciana”, jako oddzielnej serii wydawnictwa "Athenaeum. Almanah gistorii i kultury" 28 . Natomiast wespół $\mathrm{z}$ archiwistami polskimi, archiwiści białoruscy podjęli się edycji źródeł do dziejów Zachodniej Białorusi w latach 1939-1941, które przechowywane sa w Centralnym Archiwum MSWiA w Warszawie oraz w Narodowym Archiwum Republiki Białoruś w Mińsku ${ }^{29}$.

Stąd Uniwersytet Warszawski poprzez Sekcję Wschodnią Koła Naukowego Studentów Historii Sztuki pod kierunkiem dr Marii Kałamajskiej-Saeed rozpoczął - bez udziału strony białoruskiej - inwentaryzację zabytków na terytorium Białorusi ${ }^{30}$, a Biuro Pełnomocnika Rządu ds. Polskiego Dziedzictwa Kulturalnego za Granica sfinansowało prace konserwatorsko-budowlane w obiektach zabytkowych w Nieświeżu, Nowogródku i Wołoży-

26 Jak pisze współczesny polski negocjator w sprawie restytucji dóbr kultury z Białorusią: „W Centralnym Państwowym Archiwum Historycznym w Mińsku przechowywane są poważne ilości ksiąg sądowych wytworzonych na obecnym terytorium Polski w okresie XIV-XVIII w. (księgi ziemskie lubelskie, chełmskie, drohickie, krasnostawskie, suraskie i tzw. zamojskie), księgi grodzkie (drohickie, lubelskie, chełmskie, łukawskie, tzw. zamojskie) i pewne ilości akt miast (Lublina i Zamościa). Znajdu ją się tam także akta Drohickiej Komisji Cywilno-Wojskowej, magistratu miast Bielska i Brańska oraz Sądu Kapturowego Ziemi Bielskiej. Także w zbiorach Państwowego Centralnego Archiwum Historycznego w Grodnie i w Państwowym Archiwum Obwodowym w Grodnie przechowywane sa poważne ilości archiwaliów polskich, w tym akt władz szczebla powiatowego (Białystok, Bielsk, Sokółka i Drohiczyn) i wojewódzkiego z XIX i XX wieku”. W. Stępniak, Archiwalia polskie w zbiorach państw obcych, w: Archiwa polskie wobec wyzwań..., s. 58.

27 C. Goliński, Nie tylko Witebsk... Polska prosi o wyjaśnienie, „Gazeta Wyborcza”, nr 97 (3701) z 25 kwietnia 2001, s. 10; tenże, Śmierć przed Katyniem. Kolejne świadectwo zbrodni NKWD na polskich oficerach, "Gazeta Wyborcza”, nr 98 (3702) z 26 kwietnia 2001, s. 10; tenże, Te kości wciaż tam leża. Reportaźśladami ofiar terroru NKWD, „Gazeta Wyborcza", nr 113 (3717) z 16 maja 2001, s. 12-13.

28 Daslejdawannij i materiaty Metryki Wjalikago Knjastwa Litouskaga, „Metriciana”, pod red. A. Dzjarnowića, t. I, Minsk 2001.

29 Zob. Zachodnia Biatoruś 17 wrzesień 1939 - 22 czerwiec 1941. Wydarzenia i losy ludzi. Część I: Rok 1939, wstęp T. Strzembosz, Warszawa 1998.

30 Dziatalność Biura Petnomocnika Rzadu ds. Polskiego Dziedzictwa Kulturalnego za Granica, „Cenne - Bezcenne - Utracone”, nr 3, czerwiec 1997, s. 27. 
nie ${ }^{31}$ oraz poddano renowacji 12 obrazów z kościoła pobrygidkowskiego w Grodnie ${ }^{32}$. Prawdopodobnie będzie to w najbliższych latach droga, którą będą musieli podążyć także polscy archiwiści i bibliotekarze.

Nowym akcentem w polityce kulturalnej władz białoruskich było wydanie zgody na przeprowadzenie w dniu 8 czerwca 1999 r. uroczystego pogrzebu księcia Antoniego Mikołaja Radziwiłła (zmarłego na emigracji w Londynie) w kościele farnym w Nieświeżu. W podniosłej uroczystości władze białoruskie reprezentował minister Dmitryj S. Bubnowski, a polskie - prof. Andrzej Ciechanowski i Mariusz Maszkiewicz (ambasador RP w Mińsku) oraz rodzina zmarłego - wdowa Róża z ks. Czartoryskich ks. Radziwiłłowa oraz synowie Marcin i Paweł Radziwiłłowie ${ }^{33}$.

Natomiast w lutym 2002 r. w Bibliotece Akademii Nauk w Mińsku po raz pierwszy po II wojnie światowej pokazano część księgozbioru nieświeskiej ordynacji książąt Radziwiłłów. Na otwartej 26 lutego wystawie zgromadzono kilkadziesiąt starodruków opatrzonych ekslibrisami ordynatów z Nieświeża, w tym m.in. egzemplarze z kolekcji księcia Antoniego, Jerzego, Stanisława informowała zebranych dyrektor Biblioteki AN Białorusi Natalia Bierozkina - są one niezwykle cenne i jako książki, i jako świadectwo historii magnackiego rodu Radziwiłłów. Pokazano Księge przywilejów koronnych z 1600 r., tłumaczenie dzieł Plutarcha z 1578 r., wydaną sto lat później Pielgrzymkę do Ziemi Świętej Mikołaja Radziwiłła „Sierotki” oraz XVI-wieczną gramatykę języka greckiego. Stanowią one najcenniejszą część radziwiłłowskich starodruków z Nieświeża, przechowywanych w Mińsku. Ogółem Biblioteka Akademii Nauk Białorusi posiada w swoich zbiorach ponad 3 tys. starodruków ${ }^{34}$.

31 Dziatalność Biura Petnomocnika Rzadu ds. Polskiego Dziedzictwa Kulturalnego za Granica, "Cenne - Bezcenne - Utracone", nr 3, czerwiec 1997, s. 27. Prace renowacyjne dofinansowała także Fundacja Lanckorońskich z Brzezia. „Cenne - Bezcenne - Utracone”, nr 4 (22), sierpień 2000, s. 27.

32 Zob. J. Miler, Wspótpraca Biura Petnomocnika Rzadu..., s. 30-31.

33 M. Michalski, Uroczystości pogrzebowe księcia Antoniego Mikotaja Radziwitła w Nieświeżu, „Cenne - Bezcenne - Utracone”, nr 4 (22), sierpień 2000, s. 26-27.

34 C. Goliński, Z ekslibrisami Radziwittów, „Gazeta Wyborcza”, nr 50 (3958) z 28 lutego 2002, s. 11. 


\section{Polsko-ukraińskie negocjacje restytucyjne}

W dniu 8 maja 1992 r. podpisany został traktat między Rzecząpospolitą Polską a Ukrainą o dobrym sąsiedztwie, przyjaznych stosunkach i współpracy, w którym obydwie strony zobowiązały się do „ujawnienia i zwrotu dóbr kulturalnych i historycznych, które zaginęły, zostały bezprawnie wywiezione lub w inny sposób znalazły się na terytorium drugiej strony" ${ }^{35}$.

Realizując jego postanowienia, jako pierwsza na Ukrainę udała się 11 października $1992 \mathrm{r}$. delegacja muzealników polskich w ramach wymiany doświadczeń między ministerstwami kultury obu państw. W jej skład weszli: Janusz Pulnar - dyrektor Muzeum Okręgowego w Radomiu, prof. Stanisław Makowski - slawista z Uniwersytetu Warszawskiego, Włodzimierz Bielicki - scenograf i dyrektor teatrów w Warszawie i Wałbrzychu oraz prof. Zdzisław Żygulski jun. - z Muzeum Narodowego w Krakowie. Delegacja wraz z Olgiem Kaharłyckim - kierownikiem departamentu muzeów w Ministerstwie Kultury w Kijowie, zwiedziła Lwów, Równe, Żytomierz, Kijów, Perejesław, Humań, Winnicę, Kamieniec Podolski, Czerniowce i Stanisławów zapoznając się ze stanem zachowania poloników. Najleppiej zachowane polonika były przechowywane w Muzeum Krajoznawczym w Żytomierzu, które posiada osobną salę malarstwa polskiego (m.in. obraz Josepha Grassiego: Ksiqzę Józef Poniatowski na manewrach, oraz Józefa Brandta: Jeźdźcy na Kaukazie), a także we Lwowskiej Galerii Obrazów i jej filii w zamku oraz w byłym klasztorze kapucynów w Olesku. Znajduje się tam największa istniejąca kolekcja obrazów sarmackich (około 800 obiektów), pędzla czołowych malarzy polskich od XVII do XX wieku oraz bardzo liczny zbiór rzeźby (głównie sakralnej). Po II wojnie światowej ogromną rolę w ich ratowaniu odegrał obecny dyrektor Lwowskiej Galerii Obrazów - Borys Woźnicki, któremu zawdzięczamy ocalenie czterech monumentalnych obrazów batalistycznych zdobiących farę w Żółkwi: Szymona Boguszowicza Bitwa pod Kłuszynem (malowana pod okiem hetmana Stanisława Żółkiewskiego), An-

35 J. Kukułka, Traktaty..., s. 222-223. Wypracowano także wstępny projekt polsko-ukraińskiego porozumienia w sprawie współpracy kulturalnej i naukowej, który miał stanowić, że: „Strona, na terytorium której znajduja się dobra i zabytki kultury, historii oraz materiały archiwalne i zasoby biblioteczne drugiego państwa [...] będzie działać na rzecz ich ujawniania, inwentaryzacji, scalania, konserwacji, restauracji, rekonstrukcji, a także ich udostępniania. Strony będą ze sobą współpracować w tej dziedzinie, w szczególności w zakresie zespolenia kolekcji artystycznych, bibliotecznych i archiwalnych, rozproszonych na skutek wypadków historycznych" (art. 5, ust. 1). W. Kowalski, Polonica za granica. Problem prawny - problem kulturowy, „Muzealnictwo” 1993, t. 35, s. 36. 
drzeja Stecha i Ferdynanda van Kessla Bitwa pod Chocimiem oraz Martina Altomontego Bitwa pod Wiedniem i Bitwa pod Parkanami (malowane według wskazówek króla Jana III Sobieskiego) ${ }^{36}$. Efektem wizyty i wspólnych uzgodnień było rozpoczęcie inwentaryzacji poloników na Ukrainie. Od 1993 r. na terenie Ukrainy inwentaryzacją zabytków sztuki sakralnej zajmuje się Koło Naukowe Studentów Historii Sztuki Uniwersytetu Jagiellońskiego, którego opiekunem jest prof. Jan Ostrowski ${ }^{37}$. Rokrocznie publikowane są wyniki prac w serii pt. „Materiały do dziejów sztuki sakralnej na Ziemiach Wschodnich dawnej Rzeczypospolitej" 38 .

Na Ukrainę udali się także polscy archiwiści, którzy wizytę rozpoczęli od zapoznawania się z nową strukturą ukraińskiej służby archiwalnej, albowiem po odzyskaniu przez Ukrainę niepodległości w $1991 \mathrm{r}$. archiwa centralne, obwodowe i rejonowe podporządkowane zostały Głównemu Zarządowi Archiwów przy Gabinecie Ministrów Ukrainy ${ }^{39}$. Prawnie zagadnienie to uregulowała ustawa z 24 grudnia $1993 \mathrm{r}$. o narodowych zasobach archiwalnych i instytucjach archiwalnych. Za Narodowe Zasoby Archiwalne uznano wszelką dokumentację archiwalną znajdu jącą się na terytorium Ukrainy, a więc także i polonika, z których część jest własnością współczesnego państwa polskiego i podlega rewindykacji. Z kolei 20 września 1995 r. Rada Ministrów zatwierdziła Regulamin Głównego Zarządu Archiwów przy Radzie Ministrów Ukrainy, które uzyskało wyłączne prawo decydowania o włączeniu bądź wyłączeniu dokumentów z Narodowego Zasobu Archiwalnego (a więc także o ich wydaniu w ramach rewindykacji) ${ }^{40}$.

Uregulowania te poprzedziły polsko-ukraińskie rokowania archiwalne, które zwieńczono 7 lipca 1993 r. podpisaniem Porozumienia o wspótpracy między Gtównym Zarzqdem Archiwów przy Gabinecie Ministrów Ukrainy a Naczelna Dyrekcja Archiwów Państwowych Rzeczypospolitej Polskiej. Ze strony polskiej podpisał je Jerzy Skowronek (naczelny dyrektor), a z ukra-

36 Z. Żygulski jun., Muzea Ukrainy, „Muzealnictwo” 1993, t. 35, s. 39-45.

37 Zob. Dziatalność Biura Petnomocnika Rzadu ds. Polskiego Dziedzictwa Kulturalnego za Granica, „Cenne - Bezcenne - Utracone”, nr 3, czerwiec 1997, s. 27; J. Miler, Wspótpraca Biura Petnomocnika Rzadu..., s. 30.

38 Dotychczas ukazały się: tom 1 (Kościoły i klasztory rzymskokatolickie dawnego województwa ruskiego, Kraków 1993); tom 2 (Kościoły i klasztory Żółkwi, Kraków 1994); tom 3 (Kraków 1995); tom 4 (Kraków 1996); t. 5 (Kraków 1998), t. 6 (Kraków 1999).

39 E. Rosowska, Przeksztatcenia w zakresie prawa archiwalnego w krajach Europy Środkowej $i$ Wschodniej, „Archiwista Polski” 1996, R. I, nr 3, s. 55.

40 K. Nowochacki, Narodowe zasoby archiwalne i archiwa Ukrainy, „Archiwista Polski” 1996, R. I, nr 3, s. 41-44. 
ińskiej - B. W. Iwanienko (dyrektor Głównego Zarządu Archiwów). Uregulowało ono zagadnienia związane $\mathrm{z}$ dostępem do archiwaliów badaczy i archiwistów $\mathrm{z}$ obu państw, a w artykule czwartym stwierdzono, że w celu scalenia rozdzielonych zespołów archiwalnych powołana zostanie komisja ekspertów, która ustali konkretne formy tego scalenia. Ustalono ponadto, że dokumenty stanowiące własność drugiej strony, powinny być obowiązkowo zwrócone państwu lub prawowitemu właścicielowi ${ }^{41}$. Wówczas strona ukraińska przygotowała edycję źródeł dotyczącą wysiedleń ludności Ukrainy w latach 1917-1953, która zawiera także interesujące stronę polską dokumenty odnoszące się do Polaków zamieszkałych na tym obszarze ${ }^{42}$.

Ponadto na podstawie Protokotu o wspótpracy między Ministerstwem Kultury i Sztuki Rzeczypospolitej Polskiej a Ministerstwem Kultury i Sztuki Ukrainy na lata 1996-1997, który podpisano 25 listopada 1995 r., w kwietniu roku następnego powołana została polska delegacja Komisji ds. dziedzictwa kulturalnego. Komisja rozpoczęła działalność, a najaktywniej pracuje zespół do spraw archiwów, który odbył już dwa posiedzenia i ustalił zasady postępowania obydwu stron. Udało się także Pełnomocnikowi Rządu ds. Polskiego Dziedzictwa Kulturalnego za Granicą we współpracy ze stroną ukraińską powołać zespół ekspertów ds. zespołu zabytkowego z Żółkwi, na którego czele stanął prof. Ryszard Brykowski ${ }^{43}$. Biuro Pełnomocnika dofinansowało także prace konserwatorsko-budowlane w niektórych obiektach zabytkowych. Należą do nich m.in. katedra we Lwowie ${ }^{44}$ i kościół św. Wawrzyńca w Żółkwi (dawna kolegiata) ${ }^{45}$, której renowację przeprowadzali od 1991 r. studenci Wydziału Konserwacji i Restauracji Dzieł Sztuki Akademii Sztuk Pięknych

41 G. W. Boriak, Ukraina-Polszcza - natahodzujemo kontakty, „Archiwy Ukrajiny” 1993, nr 1-3; B. Woszczyński, Państwowa stużba archiwalna w roku 1996..., s. 326; tenże, Losy archiwaliów polskich..., s. 71.

42 I. Białas, Represywno-karalna systema Ukrajini 1917-1953. Suspilno-politycznyj ta istoryko-prawowyj analiz, Kijew 1994, t. 1-2.

43 W skład zespołu ponadto weszli: Jacek Miler, dr Jerzy Petrus, Jerzy Pulnar i dr Janusz Smaza. Pierwsze spotkanie zespołu odbyło się w Żółkwi w kwietniu 1998 r. Zob. J. Miler, Wspótpraca Biura Petnomocnika Rzadu..., s. 29; tenże, Kościót w Żótkwi, „Cenne Bezcenne - Utracone", nr 5, październik 1997, s. 20-21.

44 D. Janiszewska-Jakubiak, Prace konserwatorskie. Lwowska katedra obrzadku tacińskiego p.w. Wniebowzięcia Najświętszej Marii Panny, „Cenne - Bezcenne - Utracone”, nr 6 (24), grudzień 2000, s. 23-25. Zob. także: J. Petrus, Lwowska katedra obrzadku łacińskiego p.w. Wniebowzięcia Najświętszej Marii Panny, Warszawa 1999.

45 Dziatalność Biura Petnomocnika Rzadu ds. Polskiego Dziedzictwa Kulturalnego za Granica, „Cenne - Bezcenne - Utracone”, nr 3, czerwiec 1997, s. 27. 
z Warszawy i Krakowa pod kierunkiem prof, Janusza Smazy ${ }^{46}$. Ponadto podjęto wspólne polsko-ukraińskie starania o renowację Cmentarza Orląt Lwowskich - traktowany przez stronę polską nie tylko jako nekropolia, ale także symbol zwycięstwa oręża polskiego nad ukraińskim (panteon narodowy). Stało się to powodem trwających długie lata (i do dzisiaj nie rozwiązanych) sporów o napisy na nagrobkach - co uniemożliwia oficjalne otwarcie (przez głosy obydwu państw) odnowionego cmentarza, który może stać się miejscem pojednania Polaków i Ukraińców ${ }^{47}$.

Wówczas na porządku dziennym stanęło także zagadnienie odzyskania ze Lwowa zbiorów Ossolineum oraz Biblioteki Fundacji Wiktora hr. Baworowskiego ${ }^{48}$. Pozostały bowiem we Lwowie nie tylko zbiory ostatniego z Ossolińskich, lecz także zbiory bibliotek kilkunastu rodów magnackich z całej Polski: najstarsze inkunabuły i pierwodruki polskie, księgi z początków XVI w., w tym kronika Jana z Oświęcimia z 1507 r., Jana z Łańcuta i Sebastiana z Felsztyna (obie z 1517 r.), kronika Miechowity z 1511 r. wszystkie wydane w drukarniach Krakowa. Ponadto znajdują się we Lwowie najstarsze zabytki języka polskiego i rękopisy największych pisarzy i poetów polskich (m.in. Stanisława Trembeckiego i Adama Naruszewicza, Adama Mickiewicza i Juliusza Słowackiego, Aleksandra Fredry, Władysława Reymonta), listy osób znanych ze swej działalności patriotycznej

46 J. Smaza, Studenckie praktyki w Żótkwi, „Cenne - Bezcenne - Utracone”, nr 4 (10), sierpień 1998, s. 4-5 i 15.

47 J. Kuroń, Rozumiem protest Ukraińców (wywiad przeprowadzony przez Izę Chruślińską), „Gazeta Wyborcza”, nr 119 (4027) z 23 maja 2002, s. 14-15. J. Kuroń, poruszając najistotniejszą sprawę sporu o napisy na pomnikach, stwierdza, iż: „Cały ten krzyk, który się rozległ teraz $\mathrm{w}$ mediach, że nie rozumiemy, czemu radni Lwowa wciąż coś mają do zarzucenia w sprawie Cmentarza Orląt, jest infantylny. Ani Ukraińcom, ani nam, Polakom, nie idzie o te napisy. Miejmy odwagę to powiedzieć. Przecież lwowskim radnym nie o to chodzi, że tam są niewłaściwe przymiotniki: o »niepodległą“ Polskę czy »bohatersko zginęli «, i my wiemy, że przyczyny są inne. Jasne jest, że w bratobójczej wojnie po obu stronach polegli ludzie w bohaterskiej walce i po obu stronach walczono o niepodległość. Chodzi o to, że zmuszamy Ukraińców do zaakceptowania, aby ten panteon triumfu oręża polskiego stał w mieście, które oni uważają za serce Ukrainy, aby przypominał im o tamtej klęsce z 1918 r. W Polsce nie ma w żadnym miejscu i w żadnym mieście panteonu triumfu oręża niemieckiego, rosyjskiego czy żadnego innego. Polska by się na to nie zgodziła. [...] Spróbujmy sobie wyobrazić, że taki panteon stoi w Przemyślu i jest on upamiętnieniem zwycięstwa oręża ukraińskiego! Jeśli już chcemy coś dopisywać, to może strona polska zgodziłaby się napisać w dwóch językach: Bohatersko poległym w walce o niepodległą Polskę... Ukrainę... w bratobójczej walce”.

48 Część księgozbioru trafiła po II wojnie światowej do Warszawy i Wrocławia, jednak większość pozostała we Lwowie (analogicznie jak zasób Ossolineum). Zob. J. Szocki, Wiktor Baworowski - lwowski kolekcjoner i fundator biblioteki, "Przegląd Wschodni” 1998, t. 5 , z. 3 (19), s. $543-550$. 
(m.in. Jana i Jędrzeja Śniadeckich, Tadeusza Czackiego, Juliana Ursyna Niemcewicza), korespondencja królów polskich i mężów stanu, księgi metryki koronnej, największy i jedyny zbiór prasy polskiej z całego kraju i z emigracji z okresu zaborów i prawie kompletny zbiór prasy z okresu Drugiej Rzeczypospolitej (1918-1939), który był do niedawna przechowywany w wilgotnym i nie ogrzewanym kościele Jezuitów we Lwowie. Ponadto znajdują się tam także medaliony $\mathrm{z}$ puklami włosów Tadeusza Kościuszki, Józefa Bema i J. Słowackiego, fajki A. Mickiewicza, czy też zdobyty w 1831 r. sztandar rosyjski, który przekazał do Lwowa Joachim Lelewel ${ }^{49}$. Domagano się wydania całości zbiorów Bolesława Orzechowicza, powołu jąc się na akt darowizny ${ }^{50}$, a także księgozbioru Witolda Kazimierza Czartoryskiego z Honfleur ${ }^{51}$ oraz zbiorów Władysława Łozińskiego ${ }^{52}$ i kolekcji Józefa Smolińskiego ${ }^{53}$. Wnioski rewindykacyjne opracował prof. Jan Pruszyński.

Ponadto w Bibliotece Uniwersytetu im. Franka we Lwowie znajduje się spora kolekcja dokumentów dotyczących dziejów zamku i miasta Żółkwi oraz rodu Żółkiewskich, które zebrał Aleksander Sas-Czołowski ${ }^{54}$, znany przed II wojną światową historyk wojskowości i archiwista (w latach 1906-1937 dyrektor Archiwum Miejskiego we Lwowie) ${ }^{55}$. Jest to cząstka ogromnej kolekcji

49 J. Nowak-Jeziorański, Kultura polityczna, „Wprost”, nr 2 z 10 stycznia 1999 r., s. 30. Zob. także: S. F. Gajerski, Źródła do dziejów południowo-wschodniej Polski w bibliotekach i archiwach Lwowa, "Studia Historyczne” 1977, R. XX, z. 2 (77), s. 295-302.

$50 \mathrm{~W}$ akcie darowizny zbiorów z sierpnia 1919 r. czytamy: „zastrzega darowujący p. Bolesław Orzechowicz, że na ten nieprawdopodobny, a jednak możliwy wypadek, gdyby miasto Lwów, czy to wskutek wypadków politycznych, przestało mieć trwale charakter polski, gdyby pod względem narodowym polskość swoją utraciło, [...] przejść mają zbiory powyższe na własność Muzeum Narodowego w Wawelu w Krakowie, a gdyby to było trudne do wykonania, [...] stać się mają własnością Państwa Polskiego i umieszczone być mają w Warszawie, Poznaniu, Wilnie lub Gdańsku". K. Badecki, Zbiory Bolesława Orzechowicza, Lwów 1922, s. XII-XIII; J. Miler, Zbiory lwowskie (I). Zbiory Bolestawa Orzechowicza, „Cenne - Bezcenne - Utracone”, nr 3 (15), czerwiec 1999, s. 12-13.

51 J. Miler, Zbiory lwowskie (II). Księgozbiór z Honfleur, „Cenne - Bezcenne - Utracone", nr 4 (16), sierpień 1999, s. 23. Klauzule zapisu zob. w rozdziale V przy omawianiu repatriacji z Francji.

52 J. Miler, Zbiory lwowskie (III). Zbiory Wtadystawa Eozińskiego, „Cenne- Bezcenne - Utracone", nr 5 (17), październik 1999, s. 20-21.

53 J. Miler, Zbiory lwowskie (IV). Muzeum Narodowe im. króla Jana III, „Cenne Bezcenne - Utracone", nr 6 (18), grudzień 1999, s. 15 i 29.

54 Z. Wawer, Czołowski-Sas Aleksander (27 luty 1865 - lipiec 1944 Lwów), w: Stownik historyków polskich, Warszawa 1994, s. 96.

55 S. Gąsiorowski, Tatarscy niewolnicy w stużbie panów Żótkwi w XVII wieku, „Studia Historyczne" 1995, R. XXXVIII, z. 4 (151), s. 489. 
akt przechowywanych w Archiwum Głównym Akt Dawnych w Warszawie pod nazwą "Zbiory Czołowskiego" 56.

Sporo polskich archiwaliów znajduje się także w Centralnym Archiwum Historycznym Ukrainy we Lwowie (Centralnyj Derżawnyj Istoryćnyj Archiv Ukrainy u m. Lvovi), zwłaszcza do dziejów ziemi przemyskiej57. Ponadto przechowywane są tam ważne dla dziejów narodu i państwa polskiego akta: Księstwa Halicko-Wołyńskiego, zaboru austriackiego (1772-1918), okupacji rosyjskiej (1914-1915), Ukraińskiej Republiki Ludowej i Zachodnio-Ukraińskiej Republiki Ludowej (1917-1921), Galicji w II Rzeczypospolitej (1919-1939), okupacji radzieckiej (1939-1941) i niemieckiej (1941-1944) $)^{58}$, a także archiwa rodzinno-majątkowe ${ }^{59}$.

Polska wprawdzie ma tytuł prawny do ubiegania się o zbiory Ossolineum, gdyż zostały one podarowane narodowi polskiemu (a gdyby miasto Lwów przestało być etnicznie polskie, to prawo własności przechodzić miało na Uniwersytet Jagielloński) - jednak strona ukraińska traktuje je (po nacjonalizacji w 1940 r.) jako mienie państwowe. Stąd zdaniem Jana Nowaka-Jeziorańskiego „muszą się znaleźć racje przemawiające do poczucia własnego interesu Ukraińców we Lwowie. Już w 1996 r. wysunąłem taką koncepcję na łamach prasy, w rozmowach z przedstawicielami trzech ministerstw i w listach do prezydenta. O ile mi wiadomo, tylko Kwaśniewski podjął kilkakrotnie sprawę Ossolineum w rozmowach z prezydentem Kuczmą. Ossolineum musi się stać sprawą narodową. Powinien powstać Związek Muzeów i Bibliotek Polskich na rzecz odzyskania zbiorów, na którego czele stanąłby dyrektor Zamku Królewskiego, prof. Andrzej Rottermund. W rozmowie ze

56 Zob. Archiwum Gtówne Akt Dawnych w Warszawie. Informator o zasobie, Warszawa 1992.

57 A. Gliwa, Ostatni napad tatarski na ziemię przemyska w 1699 r., „Studia Historyczne” 2000, R. XLIII, nr 4 (171), s. 570.

58 O. Maciuk, Informacja o zasobie Archiwum Historycznego we Lwowie, "Archeion” 1998, t. XCIX, s. 186-189; J. Kus, Kwerenda w Centralnym Państwowym Archiwum Historycznym Ukrainy, „Archeion” 1997, t. XCVII, s. 407-408.

59 S. Pijaj, Archiwa rodzinno-majatkowe w zbiorach państwowych we Lwowie (informator), Warszawa 1995; W. Stępniak, Archiwalia polskie w zbiorach państw obcych, w: Archiwa polskie wobec wyzwań..., s. 58-59. Sporo tego rodzaju akt (zebranych po dworach i pałacach na Ukrainie po 1917 r.) znajduje się - nadal nierozpakowanych oraz zniszczonych przez wilgoć - w nieopalanych magazynach wojskowych wokół Sewastopola, podlegając najpierw Ministerstwu Obrony Narodowej ZSRR (do 1946 r. Ludowemu Komisariatowi Obrony), a od 1991 r. dowództwu wojsk ukraińskich. Zob. Grimsted Patricia Kennedy, Trophies of War and Empire. The Archival Heritage of Ukraine, World War II, and the International Politics of Restitution, Cambridge-Massachusetts 2001. 
mną wyraził on już na to zgodę - pod warunkiem, że będzie działał jako pełnomocnik szefa rządu i trzech ministerstw: spraw zagranicznych, edukacji i kultury" 60.

Nowym impulsem do działań było podpisanie 25 czerwca 1996 r. przez ministrów spraw zagranicznych obu państw w obecności prezydentów Aleksandra Kwaśniewskiego i Leonida Kuczmy Porozumienia między rzqdem Rzeczypospolitej Polskiej i Ukrainy w dziedzinie ochrony i zwrotu dóbr kultury utraconych $i$ bezprawnie przemieszczonych podczas II wojny światowej. Na jego podstawie pół roku później (w grudniu) została powołana Międzyrządowa Komisja Polsko-Ukraińska ds. ochrony i zwrotu dóbr kultury utraconych i bezprawnie przemieszczonych podczas II wojny światowej ${ }^{61}$. Komisji współprzewodniczyli - Stanisław Żurowski (podsekretarz stanu w Ministerstwie Kultury i Sztuki, Pełnomocnik Rządu ds. Polskiego Dziedzictwa Kulturalnego za Granicą), a ze strony ukraińskiej - Ołeksandr Fedoruk (przewodniczący Narodowej Komisji ds. Zwrotu na Ukrainę Dóbr Kultury przy Gabinecie Ministrów Ukrainy) ${ }^{62}$. Wówczas prezydent Kwaśniewski uważał, iż powstały podstawy do przekazania Polsce m.in. zasobu Ossolineum; jednak prezydent Kuczma powiedział, że powstanie jedynie grupa, która się tą sprawą zajmie ${ }^{63}$.

W ramach dwustronnej współpracy Biuro Pełnomocnika Rządu ds. Polskiego Dziedzictwa Kulturalnego za Granicą sfinansowało w całości lub dofinansowało prace konserwatorsko-budowlane w obiektach zabytkowych na Wschodzie. Należą do nich m.in. kościoły w: Berdyczowie, Lubomlu, Ołyce, Zasławiu i Zbarażu oraz katedra we Lwowie. Poddano renowacji obrazy

60 J. Nowak-Jeziorański, Kultura polityczna, „Wprost”, nr 2 z 10 stycznia 1999 r., s. 31 .

61 Dziatalność Biura Petnomocnika Rzadu ds. Polskiego Dziedzictwa Kulturalnego za Granica, „Cenne - Bezcenne - Utracone”, nr 3, czerwiec 1997, s. 27.

62 W skład delegacji polskiej weszli: dr Andrzej Biernat (Naczelna Dyrekcja Archiwów Państwowych), dr Adolf Juzwenko (Biblioteka Zakładu Narodowego im. Ossolińskich), prof. Edmund Małachowicz (Politechnika Wrocławska), prof. Krzysztof Migoń (Instytut Bibliotekoznawstwa i Informacji Naukowej Uniwersytetu Wrocławskiego), Joanna Pasztaleniec-Jarzyńska (Biblioteka Narodowa), prof. Jan Ostrowski (Państwowe Zbiory Sztuki na Wawelu), prof. Jan Pruszyński (Instytut Nauk Prawnych PAN), prof. Tadeusz Zalewski (Katedra Konserwacji Dzieł Sztuki Akademii Sztuk Pięknych w Krakowie). W 1998 r. K. Migoń I. Psztaleniec-Jarzyńska zastąpili w Komisji prof. Barbarę Bieńkowską i prof. Adama Manikowskiego. Zob. J. Miler, Wspótpraca Biura Petnomocnika Rzadu..., s. 28 .

63 Nieoficjalnie wiadomo było jednak, że strona ukraińska nie chce ruszać lwowskich zbiorów i najprawdopodobniej strona polska otrzyma tylko kopie mikrofilmowe. Zob. „Gazeta Wyborcza", nr 147 (2137) z 26 czerwca 1996, s. 3. 
w katedrze w Łucku oraz pomnik Adama Mickiewicza w Drohobyczu ${ }^{64}$. Na Ukrainie udało się stronie polskiej pozyskać sporo miejscowych muzealników i konserwatorów do ratowania polskiego dziedzictwa kulturalnego. Pytany jednak o kłopoty i trudności w rozmowach polsko-ukraińskich, Pełnomocnik Rządu ds. Polskiego Dziedzictwa Kulturalnego za Granicą, Tadeusz Polak 16 grudnia 1995 r. odpowiedział:

„Po tamtej stronie są też wspaniali ludzie, którzy chcą ratować wspólne dziedzictwo. Dbaja o dzieła sztuki uratowane z dworów, magnackich siedzib. My im $\mathrm{w}$ tym pomagamy, w miarę możliwości, uczestnicząc $\mathrm{w}$ pracach konserwatorskich. Wiele tych ocalonych obrazów jest wypożyczanych do Polski na wystawy. Wystarczy, że ocalały i wiemy, gdzie one są, że wspólnie troszczymy się o nasze dziedzictwo. Jeżeli chcielibyśmy cokolwiek odzyskać, to na zasadzie wzajemnych korzyści. Sporządzamy na przykład obecnie rejestr biblioteki królewskiej Stanisława Augusta Poniatowskiego ${ }^{65}$. Po śmierci króla spadkobiercy sprzedali ja gimnazjum w Krzemieńcu, a później, jeszcze przed I wojną światową, została wywieziona do Kijowa. Jest tam nadal, zreszta bardzo dobrze zachowana. Uważam, że skoro kupili, to moga nam sprzedać. Jak zwykle jest to być może kwestia ceny.

Inwentaryzujemy wiele cmentarzy, których nie uratuja ani Ukraińcy, ani my. Będziemy konserwować najcenniejsze grobowce, ale całych zespołów cmentarnych nie jesteśmy w stanie uratować. Mamy zbyt szczupłe środki. Sa pewne sukcesy: uznano za zabytkowy cmentarz Łyczakowski wraz z cmentarzem Orląt we Lwowie. Zatrzymano dewastację. W polskich grobowcach chowani są Ukraińcy, instaluje się tablice z ukraińskimi nazwiskami, niejednokrotnie mieszanych rodzin. Cóż, czas mija. Sa przypadki, że Polacy sprzedają swoje groby notarialnie. Inwentaryzujemy także wiele kościołów, zamków i innych budowli zabytkowych. Powstało nowe pojęcie konserwatorskie: ochrona przez inwentaryzację" 66.

64 Zob. J. Miler, Wspótpraca Biura Petnomocnika Rzadu..., s. 30-31. Por. A. Rudnicki, I. Dyda, Problemy i metody ochrony historycznego dziedzictwa architektury po obu stronach polsko-ukrainskiej granicy, „Przegląd Wschodni” 1999, t. VI, z. 1 (21), s. 21-25.

65 Prace nad katalogowanie 19999 woluminów Biblioteki Stanisława Augusta Poniatowskiego (przechowywanej w Centralnej Bibliotece Naukowej Akademii Nauk Ukrainy w Kijowie) ukończono w grudniu 1996 r. Ogółem w realizacji tego przedsięwzięcia w latach 1992-1996 pracowało na Ukrainie 40 polskich bibliotekarzy. Efektem ich pracy jest komputerowa baza danych z katalogiem „, Regii” dostępna w Warszawie (Biblioteka Narodowa i Biblioteka Zamku Królewskiego) oraz w Kijowie (Biblioteka Narodowa Ukrainy). Przewidziane jest także wydanie drukiem katalogu „Regii” jako wspólnej polsko-ukraińskiej edycji. H. Łaskarzewska, Biblioteka króla Stanisława Augusta Poniatowskiego przechowywana w Kijowie, "Cenne - Bezcenne - Utracone”, nr 4, sierpień 1997, s. 10-11.

66 J. Wilczak, Wciaż szukamy..., s. 53. Zob. także: R. Aftanazy, Dzieje rezydencji na dawnych kresach Rzeczypospolitej, Wrocław 1991-1997, t. 1-9; J. Szymański, Działalność Biura Petnomocnika Rzadu..., s. 3. 
Mimo podpisania w 1993 r. polsko-ukraińskiego porozumienia w sprawach archiwalnych, sprawa restytucji akt długo nie mogła ruszyć z miejsca. Brakowało bowiem aktów wykonawczych do niego. Dopiero 19 marca 1997 r. Daria Nałęcz (naczelny dyrektor) i Nina Kistruska (dyrektor Głównego Zarządu Archiwów) podpisały w Warszawie Protokót wykonawczy do „Porozumienia o wspótpracy”, który w dwunastu artykułach ustalił sposób realizacji wcześniejszych zapisów w sprawie restytucji dóbr kultury (z 7 lipca 1993 r.) ${ }^{67}$. Postanowiono dokonywać pod koniec każdego roku wymiany wykazów zespołów (po nich można będzie określić, co podlega rewindykacji lub scaleniu z zasobem drugiego państwa) ${ }^{68}$, tematów badawczych i inwentarzy archiwalnych, interesujących środowiska naukowe obu państw. Postanowiono także przystąpić do wspólnego opracowania informatora o dokumentach polskich i polonikach w archiwach ukraińskich oraz o dokumentach ukraińskich i ukrainikach $\mathrm{w}$ archiwach polskich. W ostatnim punkcie strony ustaliły, że w odstępach dwuletnich dokonywana będzie ocena aktualnego stanu współpracy - przemiennie w Polsce i na Ukrainie ${ }^{69}$.

Nową formą współpracy polsko-ukraińskiej stało się wypożyczanie poloników na wystawy organizowane w Polsce. Przykładem może być tutaj wystawa prac Jacka Malczewskiego ze zbiorów Lwowskiej Galerii Sztuki, otwarta latem 2002 r. w Sopocie. Łącznie galeria lwowska posiada 68 obrazów i szkiców oraz 18 rysunków i akwarel Malczewskiego (na 7 tys. płócien

67 B. Woszczyński, Losy archiwaliów polskich..., s. 71.

68 Jak pisze współczesny polski negocjator w sprawie restytucji dóbr kultury z Ukrainą: „Żądania dotyczące wydania oryginałów akt związane są natomiast z materiałami wytworzonymi w przeszłości na obecnym terytorium Rzeczypospolitej Polskiej. Sa to przede wszystkim księgi sigillat Metryki Koronnej nr 139 z 1666 r. i nr 262 z lat 1699-1700 (Biblioteka Akademii Nauk we Lwowie) ${ }^{a_{h}}$ księgi sądowe (grodzkie przemyskie w ilości 2715 j.a. z lat 1462-1784, ziemskie przemyskie w ilości 820 j.a. z lat 1436-1783, ziemskie przeworskie w ilości 98 j.a. z lat 1437-1774, ziemskie lubaczowskie w ilości 2 j.a. z lat 1535-1569, a ponadto ziemskie i grodzkie sanockie, ziemskie i grodzkie bełskie), akta wielu miast (m.in. Oleszyc, Dynowa, Przeworska, Babic, Krasiczyna, Radomyśla Wielkiego), sądów i urzędów wiejskich z XVII-XIX w. Oddzielnym zagadnieniem są materiały archiwalne z okresu międzywojennego wytworzone przez urzędy powiatowe z terenów dzisiejszych województw: krośnieńskiego, przemyskiego i rzeszowskiego oraz ewakuowane z Małopolski Wschodniej we wrześniu 1939 roku kilkunastu urzędów, w tym centralnych (m.in. Prezydium Rady Ministrów, Ministerstwa Spraw Wewnętrznych, Ministerstwa Spraw Wojskowych, Polskiej Komisji Likwidacyjnej w Krakowie, obok akt będących wytworem władz lokalnych Krakowa, Warszawy, Kielc). Z satysfakcją odnotować możemy, że nasi ukraińscy koledzy sami zdecydowali się na przekazanie informacji o istnieniu tych materiałów, wyrażając przy tym gotowość do rozmów na temat ich zwrotu". W. Stępniak, Archiwalia polskie w zbiorach państw obcych, w: Archiwa polskie wobec wyzwań..., s. 59.

69 B. Woszczyński, Porozumienie archiwalne z Ukraina, „Archeion” 1997, t. XCVIII, s. $303-306$. 
w swych zbiorach - w tym przedwojenne kolekcje książąt Lubomirskich, Piotra Dobrzyńskiego, hr. Leona Pinińskiego oraz Ukraińskiego Muzeum Narodowego), wśród których są wczesne obrazy: Bratankowie (1878), dwa Autoportrety z Muza (1905 i 1906), słynny tryptyk Autoportret z Faunami czy przesycony światłem Portret kobiety (1907). Wystawiono także prace dotychczas nie eksponowane w Polsce, jak: Portret dwóch mtodych męzczyzn (1899), Portret Kazimierza Pochwalskiego (1879), Wyrobnik (1892), Portret siostry artysty Heleny z Malczewskich Karczewskiej (ok. 1893), Tobiasz i trzej aniotowie (1922) oraz szkic Chtopięce gtowy (1905) ${ }^{70}$.

Jednak władze ukraińskie - mimo podpisania porozumienia o ochronie poloników na obszarze Ukrainy - dopuściły do zdemontowania i wywiezienia do Instytutu Yad Vashem w Jerozolimie ${ }^{71}$ części fresków Brunona Schulza z Drohobycza ${ }^{72}$. Po interwencji polskiego Ministerstwa Kultury i Dziedzic-

70 B. Piórkowska, Prosto ze Lwowa - Jacek Malczewski w Sopocie, „Gazeta Wyborcza”, nr 155 (4063) z 5 lipca 2002, s. 15; Malczewski ze Lwowa, „Polityka”, nr 34 (2364) z 24 sierpnia 2002, s. 47.

71 Ekipa izraelską kierował Mark Schrayberman - doskonale mówiący po rosyjsku który zwrócił się do urzędników ukraińskich o pomoc w dostaniu się do fresków. Oględziny odbyły się w obecności wicemera Drohobycza ds. kultury Nikoły Metyka, który miał być obecny nawet $w$ momencie rozpoczęcia zdejmowania fresków ze ścian. Właścicielom mieszkania (państwu Kałużnym) jako zadośćuczynienie zapłacono 100 dolarów. Prace demontażowe trwały trzy dni. M. Michalska, Ukradli Schulza. K'to je wywiózt i na czyje polecenie?, „Gazeta Wyborcza”, nr 122 (3726) z 26-27 maja 2001, s. 1; taż, Zabrali Schulza do Jerozolimy. W jaki sposób Yad Vashem wywiózt freski z Ukrainy, "Gazeta Wyborcza”, nr 125 (3729) z 30 maja 2001, s. 1.

72 Chociaż jak pisze Jerzy Pilch: „Racje ludzi z Yad Vashem są oczywiste, pragmatyczne, ściśle obliczone. W końcu nie ukrywajmy, bo sami wiemy dobrze: pozostawione w fatalnej spiżarni państwa Kałużnych freski pewnie by zmarniały. Urzędnicy wymienialiby pisma, nie byłoby grosza na prace konserwatorskie, pomysł aby parę staruszków wykwaterować, przenieść $\mathrm{w}$ inne miejsce, a w willi Landaua uczynić muzeum, to utopia czysta, jacyś niefrasobliwi wycieczkowicze raz po raz urywaliby sobie po kawałku tynku na pamiątkę, zdesperowani właściciele, dla których odkrycie w domu ściany z Schulzem miało dalsze konsekwencje literackie, zamieniło mianowicie ich życie w koszmar z Kafki i w groteskę z Mrożka, albo by nieszczęsne malunki usunęli, albo zamalowali. W końcu to jest wielkie nieszczęście: odkryć na ścianie we własnej spiżarni malowidła wielkiego artysty. [...] Racje ludzi z Yad Vashem są oczywiste, pragmatyczne, ściśle obliczone i nie do przyjęcia, ponieważ jest w nich wzgarda. Co innego jest, jak my sami (z trudem i niechętnie) konfrontujemy się z własną niemożliwością, co innego, jak kto inny ma pewność naszej niemożliwości Wtedy my gnuśne i mizerne plemiona wschodnie, unosimy się honorem, pozorujemy przedsiębiorczość i groźnie potrząsamy trzcinowymi dzidami. Racje ludzi z Yad Vashem, którzy wiedzieli ostentacyjnie i pewnie, to co my wiedzieliśmy niechętnie i niepewnie, że pozostawione swojemu losowi malunki sczezną, są bolesne podwójnie. Po pierwsze przez to, że oni arbitralnie wiedzieli, że my sobie z własnym znaleziskiem naszego autora nie poradzimy. Po drugie - boleśniejsze - przez to, że oni wiedzieli, że nam to znalezisko jest zabrać tak łatwo. [...] Mitycznym i realnym wigwamem Schulza był Droho- 
twa Narodowego ${ }^{73}$ w Ministerstwie Kultury Ukrainy ${ }^{74}$, mer Drohobycza Aleksiej Radziejewski polecił na koszt miasta wykonać prace konserwatorskie pozostałych fresków. Malowidła zdjęto ze ścian i poddano restauracji we Lwowie. Jednak po konserwacji - wystawione w Muzeum Krajoznawczym w Drohobyczu - nie przypominają one oryginałów ${ }^{75}$. Interwencje władz polskich w ambasadzie izraelskiej w Warszawie - gdzie domagano się zwrotu poloników drohobyckich - nie odniosły skutku. Natomiast przewodniczący zarządu Yad Vashem - Awner Szalew - reagując na falę oburzenia, jaka przetoczyła się przez Polskę, powiedział:

„Nie mamy zamiaru odbierać Schulza polskiej spuściźnie kulturalnej. Nikt nie kwestionuje jego przynależności do polskiej literatury i fakt ten zostanie odpowiednio podkreślony w naszej ekspozycji. Pomyślmy jednak realnie: w dawnej willi gestapowca Landaua w Drohobyczu nikt by jego malowidła nie widział. Zdaniem ekspertów, nie przedstawia ono wielkiej wartości artystycznej. Dla nas, i tylko dla nas, ma ono wartość historyczną, ponieważ jest bezpośrednio związane z Holocaustem. Przy ulicy Tarnowskiego $14 \mathrm{z}$ biegiem czasu przypuszczalnie uległoby całkowitemu zniszczeniu. Tutaj zobaczą je co roku ponad dwa miliony zwiedzających" 76 .

bycz. Wyobraźnia Schulza była wyobraźnią drohobycką i pierwszy jego język był językiem drohobyckim. Ja wiem, że freskom będzie w Jerozolimie dobrze, tyle że one nie będą na swoim miejscu. Ale w końcu co na tym świecie jest na swoim miejscu? Schulz w Drohobyczu?”. J. Pilch, Męczeństwo państwa Katuznych z Drohobycza, „Polityka”, nr 24 (2302) z 16 czerwca 2001, s. 93.

73 Do Drohobycza udała się pełnomocnik Ministerstwa Kultury i Dziedzictwa Narodowego Agnieszka Kijowska. Dokonano ekspertyzy zniszczeń, jakie miały miejsce przy zdejmowaniu fresków przez pracowników Yad Vashem w Jerozolimie. Uczestniczył w niej Borys Woznicki (dyrektor Lwowskiej Galerii Obrazów) i Benjamin Geissler (niemiecki producent filmowy, który odnalazł malowidła Schulza). Zob. M. Michalska, Eksperci w Drohobyczu. Sprawa malowidet Schulza, "Gazeta Wyborcza”, nr 136 (3740) z 12 czerwca 2001, s. 14. Zdaniem Agnieszki Kijowskiej z Muzeum Narodowego w Warszawie: „Zniszczono malowidła jako kompozycję". Natomiast Borys Woznicki stwierdził, że: „Skucie ze ścian odkrytych w Drohobyczu malowideł spowodowało w jakimś stopniu ich zniszczenie, bo były wykonane zwykłą olejna farbą, na kruchym tynku i bez żadnego podkładu". Tego samego zdania był prof. Alfred Schrayer (którego Schulz uczył przed wojną rysunku). Zob. Malowidta Schulza w kawatkach. Co zostato w Drohobyczu, "Gazeta Wyborcza”, nr 132 (3736) z 7 czerwca 2001, s. 1.

74 Po interwencji z Warszawy minister kultury Ukrainy Bohdan Stupka objął freski Schulza ochroną i wpisał $w$ rejestr zabytków narodowych, co uniemożliwia ich sprzedaż lub wywóz za granicę. M. Michalska, Ukradli Schulza..., s. 1.

75 M. Michalska, Malowidła po konserwacji. To jeszcze Schulz?, „Gazeta Wyborcza”, nr 92 (4000) z 19 kwietnia 2002, s. 16.

76 R. Frister, Nasze, wasze, cudze. Yad Vashem znaczy po hebrajsku „imię wieczne i niezniszczalne”, „Polityka”, nr 26 (2304) z 30 czerwca 2001, s. 40. Podobnie wypowiada się kierownik jerozolimskiego Międzynarodowego Instytutu Badań nad Holocaustem w Yad Vashem, Yehuda Bauer (ur. 1926), stwierdzając: „Nie widzę żadnego powodu, 
Na zaognienie sytuacji wokół kwestii fresków wpłynęła także treść tablicy pamiątkowej, umieszczonej na domu Landaua w Drohobyczu, która brzmi: „Bruno Schulz - malarz i pisarz żydowski, mistrz słowa polskiego”. Natomiast strona polska domaga się napisu: „Bruno Szchulz - Żyd-Polak - malarz i pisarz” albo "Bruno Schulz - pisarz polski pochodzenia żydowskiego". Ministerstwo Kultury i Dziedzictwa Narodowego zwróciło się do polskiego MSZ „Z prośbą o zajęcie stanowiska” w sprawie kontrowersyjnego napisu na tablicy 77 .

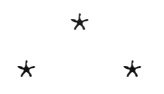

Ewakuacja dóbr kultury przez Niemców w 1944 r. z terenów zabużańskich na obecny obszar państwa polskiego, a także pozostawienie na południowo-wschodnich obszarach Polski (głównie w Bieszczadach) po $1945 \mathrm{r}$. sporej ilości ludności ukraińskiej oraz jej przymusowa deportacja od $1947 \mathrm{r}$. na Ziemie Zachodnie i Północne Polski, spowodowały przejęcie przez państwo polskie sporej liczby ukraińskich dóbr kultury. Także niektóre ukrainika trafiły do Polski w latach sześćdziesiątych przypadkowo, w ramach rewindykacji akt ze Związku Radzieckiego ${ }^{78}$.

W sprawie zwrotu polskich dóbr kultury z Ukrainy Jan Nowak-Jeziorański w liście do prezydenta RP Aleksandra Kwaśniewskiego z 19 sierpnia 1997 r. pisał, że „Spora część ukraińskiego dziedzictwa pozostała w grani-

żeby przepraszać za umieszczenie w Yad Vashem rysunków żydowskiej ofiary Holocaustu. W gruncie rzeczy jest przecież wszystko jedno, gdzie te freski będą. Nieszczęście polega na tym, że zawsze byli i pewnie zawsze będą politycy skłonni odwoływać się do manipulacji historią i prawdą, by w imię jakichś interesów wywoływać u ludzi najniebezpieczniejsze emocje. To niebezpieczeństwo towarzyszy nam stale". Bauer Yehuda, Psy tańcuchowe historii, „Gazeta Wyborcza”, nr 128 (3732) z 2-3 czerwca 2001, s. 8-9.

77 C. Polak, Tablica niezgody. Obchody 110. rocznicy urodzin Brunona Schulza, „Gazeta Wyborcza”, nr 161 (4069) z 12 lipca 2002, s. 14. Jak twierdzi pisarz Jerzy Ficowski - wybitny znawca życia i twórczości Brunona Schulza - „Napis na najnowszej tablicy to głupstwo, z którym nie chcę polemizować. Głos w tej sprawie powinien zabrać minister kultury. Schulz był potomkiem pokoleń drobnych żydowskich handlarzy galicyjskich, ale wyraźnie opowiedział się po stronie kultury polskiej. Napis powinien brzmieć: "Bruno Schulz - pisarz polski« lub po prostu "pisarz«. Jeżeli ktoś chciał podkreślić żydowskie pochodzenie Schulza, mógł to zrobić, pisząc o nim "potomek żydowskich mieszkańców Drohobycza«. On sam przecież żydowskim mieszkańcem Drohobycza nie był. Są dokumenty świadczące, że zażądał wykreślenia swojej osoby z księgi członków żydowskiej gminy wyznaniowej. Nikt do tego Schulza nie zmuszał. Pisać: "Bruno Schulz - pisarz żydowski to bzdura podobna do stwierdzenia: "Joseph Conrad - pisarz polski «". Ibidem, s. 14.

78 Zob. H. Staszewska, Akta Komitetu Tadeusza Rutkowskiego we Lwowie (1915-1925) w zasobie Archiwum Państwowego w Poznaniu, „Archeion” 1997, t. XCVIII, s. $169-174$. 
cach Rzeczypospolitej i jest rozproszona w 31 miastach, regionalnych muzeach i zbiorach ${ }^{79}$. Są wśród nich najstarsze arcydzieła unickiej sztuki kościelnej, jak również malarstwa i rzeźby ukraińskiej, księgi liturgiczne z XI w. z soboru św. Zofii w Kijowie, archiwa biskupów Kościoła unickiego, który uosabia tożsamość narodową zachodniej Ukrainy, inkunabuły i rękopisy sięgające XVI w. i XVII w., kolekcje szabel kozackich, dzieła polskich malarzy o tematyce ukraińskiej, archiwum $\mathrm{z}$ czasów wojen kozackich, a nawet kozacka czajka z czasów wojen szwedzkich, wyciągnięta z dna Zatoki Gdańskiej, są wreszcie bezcenne zbiory folkloru i ceramiki ludowej". Proponuje on także aby „zacząć od zorganizowania we Wrocławiu pod egidą Ossolineum, w osobnym pomieszczeniu, wystawy kultury ukraińskiej, skupiającej pod jednym dachem eksponaty $z$ całej Polski. Otwarcie wystawy można by połączyć z uroczystym aktem zawiązania braterskiego partnerstwa miasta Wrocławia z Lwowem. Reszta zależałaby już tylko od decyzji miasta Lwowa. Czy wolą mieć u siebie pamiątki dziejów polskich, czy ukraińskich. Rozwiązanie takie przyczyniłoby się walnie do scementowania przy jaźni polsko-ukraińskiej i zamknięcia bolesnego rachunku przeszłości. Proponowane rozwiązanie wymaga czasu i cierpliwości. Nie łudźmy się, by przyniosło je planowane na koniec stycznia [1999 r. - D.M.] posiedzenie prezydenckiej polsko-ukraińskiej komisji mieszanej. Chyba, że zadowolimy się oglądaniem zd jęć i mikrofilmów" 80.

\section{Polsko-litewskie negocjacje restytucyjne}

Od odzyskania niepodległości w 1991 r. archiwalia historyczne Litwy przechowywane są w dwóch archiwach: 1) Archiwum Historycznym Państwa Litewskiego (Lietuvos Valstybes Istorijos Archyvas) - które posiada zasób wytworzony do 1918 r. (gromadzi ponad 13 mln jednostek archiwalnych,

79 Zob. Z. Żygulski, Stara broń w polskich zbiorach, Warszawa 1982 (pod poz. 55 przedstawiona jest buława księcia Michała Seweryna Wiśniowieckiego); S. Radoń, Materiały archiwalne dotyczace Ukrainy, Ukraińców i stosunków polsko-ukrainskich, przechowywane w Archiwum Państwowym w Krakowie, „Krakowski Rocznik Archiwalny” 1996, t. 2 , s. $177-178$.

80 J. Nowak-Jeziorański, Kultura polityczna, „Wprost”, nr 2 z 10 stycznia 1999 r., s. 31 . 
tj. 16 tys. m.b. akt) ${ }^{81}$; 2) Litewskim Centralnym Archiwum Państwowym (Lietuvos Centrinis Valstybinis Archiv) - które posiada zasób powstały po roku 1918 (ok. 2200 zespołów archiwalnych złożonych z około 3 mln jednostek archiwalnych) ${ }^{82}$. Ich udostępnienie badaczom polskim stało się przedmiotem dwustronnych negocjacji między archiwistami z Polski i Litwy.

W dniu 11 czerwca 1993 r. w Białymstoku doszło do podpisania porozumienia o współpracy między Naczelną Dyrekcją Archiwów Państwowych (Jerzy Skowronek) a Generalną Dyrekcją Archiwów Litwy (Gediminas Ilgunas). Dotyczyło ono głównie wymiany informacji o lituanikach w Polsce i polonikach na Litwie. Jako przykład podano przechowywany w Archiwum Państwowym w Białymstoku zespół akt „Kamera Wojenna i Domen z lat 1795-1807", który dotyczy dzisiejszego terytorium Litwy oraz odnoszące się do Białostocczyzny akta $z$ okresu międzywojennego, a przechowywane w Centralnym Archiwum Historycznym Litwy 83 .

Natomiast 26 października 1994 r. został podpisany w nadgranicznym Mariampolu polsko-litewski protokół wstępny o przygotowywaniu wymiany dokumentów metrykalnych zgodnie z zasadą pertynencji. Strona litewska przedstawiła możliwość wymiany za lituanika około $13,5 \mathrm{~m}$. b. akt metrykalnych (67 tys. klatek mikrofilmowych kopii tych akt) dotyczących dekanatów: białostockiego, knyszyńskiego i sokólskiego z pierwszej połowy XIX w. ${ }^{84}$

Dalsze rozmowy naczelnego dyrektora AP J. Skowronka w Departamencie Archiwów Litwy oraz w Litewskim Państwowym Archiwum Historycznym zaowocowały uzgodnieniem harmonogramu prac archiwistów Polski i Litwy, który zakładał, że: 1) obie strony przygotują ekwiwalentną wymianę oryginałów i mikrofilmowych kopii ksiąg metrykalnych (o objętości 13,5 m.b.); 2) wymiana mikrofilmów nastąpi w postaci kopii pozytywowych przeznaczonych do czytania (pozytywy typu diazo); 3) w najbliższym czasie każda ze stron przygotuje (i prześle partnerowi) dokładny wykaz jednostek archiwalnych przygotowanych do rewindykacji wymiennej (z dokładnym

81 B. Woszczyński, Archiwum Historyczne Litwy, „Archiwista Polski” 1997, R. II, nr 1 (5), s. 40-42. Poprzednikami Archiwum Historycznego Państwa Litewskiego były: w latach 1940-1957 Centralne Archiwum Litewskiej SRR, a w latach 1957-1991 - Centralne Archiwum Historyczne LSRR.

82 Zob. szerzej: M. Kocójowa, Przewodnik po zbiorach rękopisów w Wilnie, Kraków 1993.

83 H. Majecki, Porozumienie o polsko-litewskiej wspótpracy archiwalnej, „Archeion” 1995, t. XCV, s. 194-195; B. Woszczyński, Losy archiwaliów polskich..., s. 70.

84 J. Skowronek, Wspótpraca z archiwami litewskimi: warunki - rezultaty - perspektywy, „Archeion” 1997, t. XCVII, s. 79. 
określeniem liczby stron, klatek mikrofilmowych oraz m.b. akt);4) przedstawiciele (po jednym) archiwów z Wilna i Suwałk, realizując wzmiankowaną rewindykację, odbędą jednodniowe wizyty robocze, aby zaznajomić się ze stanem przygotowywanych do rewindykacji ksiąg i ich mikrofilmami oraz aby uzgodnić szczegóły dokonania tych rewindykacji; 5) strona litewska zobowiązana jest uzyskać zgodę specjalnej komisji rządowej (i premiera), a strona polska aprobatę Rady Archiwalnej na dokonanie tej wymiany; 6) strona litewska weźmie pod uwagę możliwość uwzględnienia w tej wymiennej rewindykacji ponadto 16 jednostek archiwalnych z Centralnego Archiwum Metrykalnego; 7) najdalej w ciągu 4-5 miesięcy zostanie przeprowadzona wymienna rewindykacja ksiąg metrykalnych. Obie strony zadeklarowały chęć nadania temu aktowi uroczystego symbolicznego charakteru, zarówno na Litwie, jak i w Polsce (wzajemne przekazanie akt odbywać się będzie etapami po obu stronach) ${ }^{85}$.

Ponadto kwerendy archiwalne przeprowadzała Wojskowa Komisja Archiwalna, wykonując ponad 100 tys. kserokopii z akt litewskiego MSZ dla lat 1918-1939, dokumentacji internowanych Polaków od września 1939 do lipca 1940 r. (w obozach w Kalwarii i Birsztanach) oraz z akt litewskiego KGB i NKWD - przechowywanych w centralnym Archiwum Państwowym oraz w Litewskim Archiwum Specjalnym byłego KGB ${ }^{86}$.

W dniu 6 stycznia 1995 r. - niezależnie od umowy między archiwami Polski i Litwy - ambasador Litwy w Polsce Antanas Valionis przekazał Głównej Komisji Badania Zbrodni Przeciwko Narodowi Polskiemu kopie dokumentów dotyczących 52 Polaków zamordowanych w Wilnie w latach 1944-1947 przez NKWD. Zbrodni tych dokonano w wileńskim dworku „Tusculanum”, przekształconym przez NKWD w więzienie. Według władz litewskich zamordowano tam łącznie ok. 800 osób, w większości Litwinów 87 .

Natomiast w lutym 1995 r. podczas prac remontowych w kościele ojców bernardynów w Wilnie ekipa remontowa natknęła się na skrzynie z materiałami archiwalnymi dotyczącymi Armii Krajowej. Po wstępnej analizie zachowanych akt okazało się, iż niestety nie natrafiono na szczątki urzędowego archiwum Armii Krajowej na Litwie, lecz na materiały Biura Informacji i Propagandy Okręgu Wileńskiego Armii Krajowej z lat 1941-1945 (z prze-

85 J. Skowronek, Wspótpraca z archiwami..., s. 79-80.

86 R. Masłowski, Informacja o wybranych dokumentach..., s. 125-126.

87 Informacja PAP, „Gazeta Wyborcza”, nr 6 (1694) z 7-8 stycznia 1995, s. 2. 
ważającą ilością akt z lat 1943-1944). Znaleziono m.in.: Wytyczne organizacyjne akcji pomocy żotnierzom, 17 marca 1943; kilka zeznań świadków o indywidualnym terrorze partyzantów radzieckich przeciw przedstawicielom polskiego społeczeństwa na Litwie; Rozporzqdzenie o tymczasowym uregulowaniu stanu prawnego na terenie Wileńskiego Okregu Wojskowego; rozkaz „Wilka" nr 4 z 9 kwietnia 1944 r.; rozkaz organizowania służb ochrony powszechnej; przegląd prasy nielegalnej i legalnej na Litwie; Instrukcja w sprawie zagwarantowania bezpieczeństwa wewnatrz kraju w okresie przejściowym (29 kart); Instrukcja grup dywersyjnych „N" $i$ „Wyżty”; instrukcje sanitarne; materiały i instrukcje dotyczące przygotowania przemysłu wojennego (prawdopodobnie jako element przygotowań do realizacji akcji „Burza”); Liga Służby Polsce (publikacja periodyczna „Czyn”); instrukcja o szkoleniu kadry instruktorskiej; instrukcja o organizacji Biura Informacji i Propagandy Armii Krajowej na Litwie; sprawy wyznaniowe i stosunki narodowościowe na Litwie (anonimowa ekspertyza); Instrukcja dla „E” (Kowno); korespondencja między dowódcami partyzantów polskich i radzieckich; instrukcja dotycząca Referatu „K” (antykomunistycznego); ekspertyzy i informacje dotyczące narodu białoruskiego i działań Generalnego Komisarza Białoruskiego; Litewski Biuletyn Informacyjny ( Przegląd Prasy”); instrukcja o walce przeciw niemieckim związkom zawodowym na Litwie; ekspertyza o systemie aprowizacyjnym; ekspertyza o rolnictwie na Litwie; Uchwata Rady Narodowościowej określajaca stosunki polsko-ukraińskie; Sytuacja Niemców, Polaków i Rosjan na ziemiach wschodnich II Rzeczypospolitej; Zarys stosunków polsko-litewskich od 1918 r. (26 kart); Komunikaty Biura Informacji i Propagandy o Litwie; Sprawozdanie z podróży do Rygi; sprawozdanie "Nemo" za maj 1944 r. (głównie o sytuacji w poszczególnych miastach); sprawozdanie „Wiano" dla „Konga” 1944 r.; O niemieckiej prasie $i$ cenzurze (ekspertyza); komunikaty radia "Świt"; szkic historyczny o powstaniu i organizacji brygady Łupaszki; wezwanie mobilizacyjne (w przewidywaniu działań powstańczych); relacje o więzieniu i śledztwie w Gestapo i pobycie w więzieniu; spis Polaków i osób innych narodowości podejrzanych o nielojalność wobec AK i współpracę z Niemcami (lista 750 nazwisk, uwzględnia następujące dane: imię i nazwisko - adres - wiek - zawód - powód umieszczenia na liście); raport o polskich oddziałach partyzanckich; sprawozdanie Inspektoratu "Wir" i "A"; informacje o ruchach i transportach wojsk, o akcjach partyzanckich; Statut tajnego szkolnictwa polskiego na terenie gminy; dwie teczki rozsypów bez podziału na wyodrębnione grupy akt. Ponadto znaleziono część zbioru polskiej prasy podziemnej, w tym pojedyncze numery periodyków: „Ojczysta Orka”, „Niepodległość. Organ Ziemi 
Wileńskiej”, „Świt Polski” (wyd. w Nowogródku), „Echa leśne”, „Sztandar Wolności” (organ Związku Patriotów Polskich), "Rzeczpospolita Polska" (wyd. w Warszawie, z lat 1943-1944), „Insurekcja”, „Archiwum Litewskie”, „Biuletyn Informacyjny” (zeszyt ze szczegółową instrukcją, jak należy zbierać i przekazywać informacje); „Biuletyny BIP-u” (Oddziału Wileńskiego), „Biuletyny PAT-a”, „Biuletyn informacyjny radia wileńskiego", „Liga Silnej Polski - Czyn”, „Orka. Organ katolicki”, „Jednością silni”, „Sersum Corda. Organ duszpasterstwa Polskich Sił Zbrojnych", „Polska w walce”, "Pobudka” (wyd. w Wilnie), „Wiadomości Polskie”, „Program Polski Ludowej”, "Litwa wczoraj - dziś i jutro" oraz „Uderzenie" 88 .

Ponadto w dniach 6-17 listopada 1995 r. w ramach bezdewizowej wymiany z zasobem Litewskiego Państwowego Archiwum Historycznego w Wilnie zapoznał się Sławomir Filipowicz z Archiwum Państwowego w Suwałkach. Przygotował on wykaz akt dotyczących Suwalszczyzny, które po zmikrofilmowaniu mają być przekazane stronie polskiej w ramach tzw. rewindykacji wymiennej ${ }^{89}$.

Prowadzona w latach 1995-1998 wymienna rewindykacja polsko-litewska doprowadziła do przekazania przez Archiwum Państwowe w Suwałkach do Archiwum Historycznego Państwa Litewskiego nieco ponad 70 tys. klatek mikrofilmów ksiąg stanu cywilnego wytworzonych w latach 1808-1912 na terenie środkowej i wschodniej części dawnego powiatu Sejny, po I wojnie światowej włączonej do Litwy. Natomiast Litwini przekazali do Archiwum Państwowego w Białymstoku także nieco ponad 70 tys. klatek mikrofilmów wykonanych $\mathrm{z}$ dziewiętnastowiecznych ksiąg metrykalnych parafii dekanatów białostockiego, knyszyńskiego i sokólskiego. Ponadto podczas pobytu delegacji archiwistów polskich w dniach 21-23 października 1998 r. w Wilnie, generalny dyrektor Departamentu Archiwów Litwy Vidas Grigoraitis oraz zastępca naczelnego dyrektora Archiwów Państwowych RP Władysław Stępniak przekazali sobie spisy zespołów, dotyczących Polaków i Polski, które znajdują się w archiwach litewskich oraz dotyczących Litwinów i Litwy, które są przechowywane w archiwach polskich. Uzgodniono także coroczną wymianę około 20 tys. klatek mikrofilmów (jeśli nie przeszkodzą temu względy finansowe i techniczne). Na zakończenie obrad dyrektorzy V. Grigoraitis i W. Stępniak podpisali Protokót wykonawczy do „Porozumie-

88 J. Skowronek, Wspótpraca $z$ archiwami..., s. 80-82.

89 S. Filipowicz, Pobyt w Litewskim Państwowym Archiwum Historycznym w Wilnie, „Archeion” 1997, t. XCVII, s. 400-405. 
nia o wspótpracy między Naczelna Dyrekcja Archiwów Państwowych w RP a Generalna Dyrekcja Archiwów Litwy"90.

Ponadto na Litwie bardzo zaawansowane są prace nad edycją kolejnych tomów Metryki Litewskiej, które prowadzi Litewski Instytut Historyczny (dawniej Akademii Nauk Litewskiej SRR). W 1993 r. - kontynuując wydawanie ksiąg drukowanych do 1910 r. w serii pierwszej ${ }^{91}$ - opublikowano $\mathrm{w}$ języku rosyjskim ze wstępem w języku litewskim i angielskim, liczący 402 strony dużego formatu tom pt. Lietuvos Metrika (1427-1506), Knyga Nr 5, którą opracował Egidijus Banionis (Vilnius 1993). Dwa lata później ukazały się kolejne tomy tej serii: Lietuvos Metrika (1528-1547), 6-oji Teismu bylu knyga (Kopija - XVI a. pabaiga), przygotowane przez Stasysa Lazutka i Irenę Valikonytè, oraz Lietuvos Metrika. Knyga Nr 8 (1499-1514), którą opracowali: Algirdas Baliulis, Romualdas Firokovičius oraz Darius Anatanavičius. W roku 1996 ukazała się: Lietuvos Metrika. Knyga Nr 564 (1553-1567), opracowana przez Algirdasa Baliulisa ${ }^{92}$. Teraz należy oczekiwać - mimo trudności finansowych - edycji kolejnych tomów, z których dwa (księgi 64 i 224) są już przygotowane do druku.

Jednak nadal pozostaje nierozstrzygnięta sprawa zwrotu archiwaliów dotyczących obecnego terytorium państwa polskiego ${ }^{93}$.

90 T. Radziwonowicz, Polsko-litewska wspótpraca archiwalna, „Archeion” 1999, t. C, s. $428-429$.

91 Poza serią ukazały się: Metryka Litewska. K'sięga Sigillat 1709-1719, oprac. A. Rachuba, PWN, Warszawa 1987; Metryka Litewska. Rejestry podymnego. Województwo wileńskie 1690 r., oprac. A. Rachuba, Warszawa 1989. Zob. także: Urzędnicy centralni $i d y-$ gnitarze Wielkiego Księstwa Litewskiego XIV-XVIII wieku. Spisy, oprac. H. Lulewicz i A. Rachuba, Poznań 1994; Metryka litewska. Księga wpisów nr 131 [od roku 1658], oprac. A. Rachuba, Warszawa 2001.

92 Zob. K. Pietkiewicz, Nowa edycja Metryki Litewskiej, „Lituano-Slavica Posnaniensia" 1997, t. VII, s. 133-153.

93 Jak pisze współczesny polski negocjator w sprawie restytucji dóbr kultury z Litwą: „W Archiwum Historycznym Państwa Litewskiego przechowuje się przynależne do obecnego terytorium Polski akta: Guberni Augustowskiej i Suwalskiej, Zarządu Guberni Suwalskiej, Zarządu Guberni Augustowskiej, Kancelarii Gubernatora Suwalskiego, Zarządu Naczelnika Wojskowego Guberni Suwalskiej, Komisji do Spraw Chłopskich Guberni Suwalskiej, Suwalskiego Sądu Okręgowego, Zarządu Żandarmerii Guberni Suwalskiej, Zarządu Majątków Guberni Łomżyńskiej i Suwalskiej, Izby Skarbowej Guberni Suwalskiej, Zarządu Akcyzy Guberni Suwalskiej i Łomżyńskiej, Kasy Oszczędnościowo-Kredytowej Guberni Suwalskiej, Towarzystwa Dobroczynności i Opieki Społecznej. Poważnym problemem jest także przechowywanie akt administracji polskiej $\mathrm{z}$ okresu międzywojennego i pewnych ilości ksiąg metrykalnych dotyczących miejscowości położonych w obrębie dzisiejszego terytorium Polski". W. Stępniak, Archiwalia polskie w zbiorach państw obcych, w: Archiwa polskie wobec wyzwań..., s. 59. 


\section{Polskie plany restytucyjne}

Państwa Europy Środkowowschodniej przyjmowały i przyjmują powszechnie akceptowaną zasadę pertynencji (czyli przynależności terytorialnej) jako podstawę określającą przynależność dokumentu do zbiorów danego archiwum ${ }^{94}$. Oznacza ona, że dokumenty wytworzone na danym terytorium muszą być przekazywane do archiwum obejmującego swym zasięgiem to terytorium. W razie zmiany granic i przynależności państwowej ziem, archiwum (i jego zasoby) także zmieniają przynależność państwową, ale nie mogą być przeniesione do innego archiwum w państwie dotychczas sprawującym władzę nad owym terytorium ${ }^{95}$.

Na tych zasadach opiera Polska swoje roszczenia restytucyjne wobec Ukrainy, Białorusi i Litwy. Na terytorium każdego z tych państw znajdują się polskie dobra kultury przemieszczone $\mathrm{z}$ obecnego terytorium państwa polskiego w wyniku działań wojennych, konfiskat lub grabieży, ale także ewakuacji (w czasie I i II wojny światowej). Po 1990 r. - mimo powszechnego akceptowania europejskich standardów postępowania z dobrami kultury innych państw - wszelkie procesy restytucyjne zostały całkowicie zablokowane. Nadal w archiwach państw sąsiadujących z Polską znajdują się miliony poloników prawnie należących się Rzeczypospolitej Polskiej. Ale również Polska posiada na swoim terytorium w zasobach archiwów i bibliotek dobra kultury państw, wobec których zgłasza określone roszczenia restytucyjne.

Dlatego też polskie plany restytucyjne zależne są przede wszystkim od stanowiska Polski w sprawie zwrotu dóbr kultury innych państw znajdujących się na naszym terytorium, a także arystokracji polskiej (która w przypadku odzyskania dóbr kultury, miałaby prawo wywiezienia ich do aktualnego miejsca zamieszkania - czyli głównie poza granice Polski) ${ }^{96}$. Stąd

94 Do tej wykładni skłaniał się też chadecko-liberalny rząd Helmuta Kohla. Jednak po wyborach 1998 r. rząd Gerharda Schrödera zasadę pertynencji zanegował w negocjacjach z Polska.

95 J. Skowronek, Misja archiwisty $i$ problemy rewindykacji archiwów - specyfika Europy Środkowo-Wschodniej XIX $i$ XX w., „Archeion” 1995, t. XCIV, s. 16.

$96 \mathrm{~W}$ tragicznej sytuacji może znaleźć się Muzeum Narodowe w Warszawie. Jak pisze Piotr Sarzyński: „Przez całe dziesięciolecia stołeczne muzeum chlubić się mogło przedsiębiorczością jego szefa prof. Stanisława Lorentza. Dość powiedzieć, że w latach 1945-1990 Muzeum Narodowemu przybyło 600 tys. obiektów, z których tylko 60 tys. zostało zakupionych. Dziś gliniane nogi kolosa coraz bardziej kruszeją. Tym bardziej, że najwięcej dzieł o wątpliwym statusie własności znaleźć można wśród obiektów najcenniejszych, znajdujących się w ekspozycjach stałych. Dane są przerażające. Otóż gdyby uwzględnić wszystkie 
należy spodziewać się, że w sprawie Bibliotęki Pruskiej „odmowa zwrotu największej skarbnicy niemieckiej kultury groziłaby na dłuższą metę konfliktem podważającym historyczne osiągnięcie, jakim stało się pojednanie z Niemcami, przez które prowadzi droga do wspólnoty europejskiej i atlantyckiej. Z kolei Polska jest taką samą drogą na Zachód dla Ukrainy. Odrzucenie moralnego prawa Niemców do odzyskania największego skarbu ich dziedzictwa przekreśliłoby raz na zawsze możliwości odzyskania Ossolineum". Stąd Jan Nowak-Jeziorański konstatuje dalej, iż: „Polska w dobrowolnym geście przyjaźni wobec zachodniego sąsiada powinna uznać, że Biblioteka Pruska jest własnością narodu niemieckiego. Ale mamy prawo potraktować tę własność jako zastaw. Zwrot tych bezcennych zbiorów musi być uzależniony zarówno od oddania mienia zabranego, jak i odszkodowania za dobra zniszczone. Jeśli nie pełnego, to co najmniej odpowiadającego wartości zastawu" 97.

Podstawowe pytanie dotyczy przede wszystkim cezury czasowej, od której Polska może ubiegać się o restytucję swoich dóbr kultury. Z pewnością dotyczy ona całego wieku dwudziestego, a może odnosić się także do okresu zaborów. Wcześniejsze rabunki polskich dóbr kultury - głównie w XVII i na początku XVIII w. - należy traktować jako dobra trwale utracone ${ }^{98}$ i zadowolić się jedynie - jeśli jeszcze istnieja - ich repartycją (wykonaniem kopii) ${ }^{99}$.

żądania rewindykacyjne, to w Galerii Sztuki Średniowiecznej pozostałoby 5 proc. eksponatów, w Galerii Sztuki Starożytnej i Galerii Sztuki Zdobniczej - połowa, zaś w Galerii Malarstwa Polskiego - 40 proc. [...] W przypadkach kolekcji odzyskiwanych przez kolejne arystokratyczne rody pozostają więc długie i żmudne negocjacje, stawianie za wzór Czartoryskich, którzy dogadali się w Krakowie i Raczyńskich - w Poznaniu. Jednak - co przyznaje dyr. Ferdynand Ruszczyc - te rozmowy są bardzo trudne, a potomkowie wielkich rodów ujawniają bardzo ograniczoną gotowość zrozumienia interesów kultury narodowej. Zdecydowanie więcej stanowczości wykazywać natomiast należy wobec pretensji zgłaszanych do mienia poniemieckiego. Rozdrabnianie wielkich muzealnych kolekcji nie powinno mieć miejsca [podkr. D.M.]”. P. Sarzyński, Rozbieranie zbiorów, „Polityka”, nr 31 (2309) z 4 sierpnia 2001, s. 54-55.

97 J. Nowak-Jeziorański, Kultura polityczna, „Wprost”, nr 2 z 10 stycznia 1,999 r., s. $30-31$.

98 Podobnie postępują inne państwa. Na przykład Belgia nie zgłasza pretensji do przechowywanego w Muzeum Narodowym w Gdańsku „Sądu Ostatecznego” Hansa Memlinga, który w XV w. zamówiła i zadatkowała Antwerpia, jednak po drodze zrabowali obraz gdańscy korsarze. „Polityka”, nr 32 (2310) z 11 sierpnia 2001, s. 35.

99 Pod tym względem spore osiągnięcia były już w czasach PRL. Zob. Katalog mikrofilmów $i$ fotokopii poloniców $z$ archiwów zagranicznych, Wydawnictwo NDAP, Warszawa 1965-1987, z. 1-6. 
Natomiast gdy nie jest możliwe rozdzielenie zasobu archiwalnego (nie tylko ze względu na zasadę proweniencji), wówczas trzeba będzie skorzystać ze środka specjalnego - tzw. koncepcji wspólnego dziedzictwa kulturalnego która propagowana jest przez UNESCO i Międzynarodową Radę Archiwów, wtedy gdy nie jest możliwy podział zespołu archiwalnego lub zasobu danego archiwum bez naruszenia jego wartości historycznej, administracyjnej i prawnej. Praktyczne zastosowanie tzw. koncepcji wspólnego dziedzictwa kulturalnego oznacza pozostawienie materiałów archiwalnych w posiadaniu jednego z zainteresowanych nimi państw. Państwo takie przejmuje na siebie obowiązek zarządzania tymi materiałami archiwalnymi i ich ochroną, a jego prawa do wykorzystywania tych materiałów w celach naukowych i innych są takie same jak drugiego państwa, którego ta koncepcja także dotyczy ${ }^{100}$.

Od 1999 r. - jak podała naczelny dyrektor Archiwów Państwowych RP Daria Nałęcz - polska służba archiwalna prowadzi indeksację (w sieci komputerowej) rozproszonych po całym świecie (w muzeach, bibliotekach, archiwach oraz $\mathrm{w}$ zbiorach prywatnych) poloników ${ }^{101}$. Prace te wykonywane są w ramach programu Rady Europy pt. Odtworzenie pamięci Polski (Reconstruction of the Memory of Poland), którego celem jest dostarczenie informacji o źródłach do dziejów Polski i Polaków z okresu 1772-1945 oraz stworzenie metodologii poszukiwań i zbierania informacji o zasobach rozproszonych w różnych państwach lub na terenie tych państw ${ }^{102}$. W pierwszej kolejności będzie dokonana rejestracja źródeł do dziejów Polski w zbiorach państw rozbiorowych (Austrii, Niemiec i Rosji) oraz Ukrainy, Litwy i Białorusi. Dyrektorem programu został Władysław Stępniak - zastępca naczelnego dyrektora Archiwów Państwowych RP ${ }^{103}$. Program Rady Europy pt. Odtworzenie pamięci Polski został poparty przez historyków polskich, którzy w apelu do sekretarza generalnego Rady Europy Daniela Tarschysa z 6 marca 1998 r. pisali, iż:

100 W. Stępniak, Problemy spuścizny archiwalnej w stosunkach Polski z Biatorusia, Litwa, Ukraina i Rosja, „Sprawy Międzynarodowe” 1992, nr 1-2, s. 114.

101 „Wprost”, nr 28 z 15 lipca 2001, s. 50. Zob. także: D. Nałęcz, Europejska polityka dostępu do archiwów, „Archeion” 1998, t. XCIX, s. 54-74.

102 Reconstruction of the Memory of Poland. Sources to the History of Poland and Poles (1772-1945) in the European countries' holdings, Warsaw 2000, s. 5.

103 B. Woszczyński, $Z$ obrad Rady Archiwalnej..., s. 68. 
„Doświadczając w swojej codziennej pracy, jak tragicznie odcisnęły się na polskim rządowym zasobie archiwalnym kolejne kataklizmy dziejowe, zwłaszcza utrata niepodległości w końcu XVIII w. oraz zniszczenia i grabieże dokonane przez zaborców i okupantów w czasie II wojny światowej, zwracamy się do Pana z apelem, by siła autorytetu Pana i pańskiego urzędu, zechciał Pan wesprzeć ideę realizacji programu przyjętego przez sekretariat Międzynarodowej Rady Archiwów i grupę ekspertów Rady Europy obradującej pod hasłem „Electronic Publishing, Books and Archives" na spotkaniu 13 stycznia br.

Los archiwów polskich odpowiadał rytmowi wydarzeń politycznych. Od $1795 \mathrm{r}$. tułały się one po rozległych terytoriach mocarstw rozbiorowych. Przewożone z miejsca na miejsce, poddawane wielokrotnym selekcjom, nie poważane, traciły swe pierwotne walory. Ginęły, tak jak zginęły instytucje, które je wytworzyły. Ich miejsce zajęły nowe urzędy. Część z nich reprezentowała nowe, dalekie metropolie, część miała lokalny charakter. Wszystkie rejestrowały życie podbitego narodu. Ale nie całego. Najbardziej aktywni i najmniej pogodzeni z utrata niepodległości, najciężej doświadczeni przez represje wzmagające się po każdym z narodowych powstań, zmuszeni byli do emigracji. Poza granicami obszaru narodowego, korzystając z gościnności innych ludów, tworzyli organizacje, które zastępowały struktury nieistniejącego państwa.

Realizacja nadziei niepodległościowych i odbudowa państwa w 1918 r. nie zbiegły się z odbudową zasobów archiwalnych. Dawni zaborcy wywieźli dokumentację, nad która wcześniej sprawowali nadzór. Polacy zaś, którzy zaczęli ściągać z wygnania, zostawili w krajach dotychczasowego pobytu dokumentację swojej aktywności. $\mathrm{Na}$ mocy traktatów pokojowych, kończących I wojnę światową, Polsce udało się w pełni odzyskać tylko akta zaboru austriackiego.

Wybuch kolejnej wojny pogłębił dzieło zniszczenia. Z premedytacja unicestwiono główne historyczne archiwa państwa i archiwa instytucji centralnych, w tym ministerstw, część materiałów wojska okupacyjne wywiozły do Niemiec i ZSRR. Tam też znajdują się do dzisiaj. Wraz ze zmianami granic Polska oddała państwom sukcesorom na terytoriach wschodnich zasoby archiwalne takich wielkich ośrodków jak Wilno, Lwów, czy Grodno. Nie otrzymała zaś analogicznych zbiorów na przejętych obszarach.

Dla budowania rzetelnej wiedzy o przeszłości, bez zakłamań i skrótów, dla pełnego poznania procesów historycznych, dla prawidłowego kształtowania świadomości narodowej, potrzebna jest szeroka wiedza. Wiedzy tej jednak nie można poświęcić opierając się na szczątkowym materiale źródłowym. Dlatego tak ważne jest dla nas poszerzenie bazy archiwalnej, ujawnienie zasobów, o których istnieniu wiemy mało lub nic.

Przedstawiony projekt rejestracji źródeł do historii Polski, znajdujących się poza aktualnymi granicami państwa, wychodzi naprzeciw procesom integracyjnym zachodzącym w Europie. Przyczynia się do minimalizowania negatywnych skutków dotychczasowych podziałów oraz usuwania antagonizmów, które dzieliły, ale już dzielić nie muszą. Stać się może przykładem i wzorem dla tych wszystkich naro- 
dów, których dzieje były równie burzliwe, a które też pragną posiąść pełną wiedzę o historycznym swoim dziedzictwie" 104.

Polska do tego zadania przygotowywała się już od kilku lat. Jedną z form uzyskiwania informacji na ten temat są organizowane przez stronę polską konferencje i sympozja naukowe $z$ udziałem gości zagranicznych, a także bieżące śledzenie wydawnictw archiwalnych państw, wobec których Polska wysuwa żądania rewindykacyjne. Jedną z metod zbierania informacji są organizowane konferencje naukowe o polonikach na wschodzie.

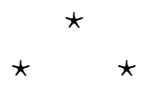

Archiwum Główne Akt Dawnych w Warszawie było w dniach 15-16 kwietnia 1996 r. gospodarzem trzeciej międzynarodowej konferencji poświęconej archiwom rodowym (pierwsza dotyczyła archiwów Radziwiłłów i odbyła się w 1994 r. w Nieborowie, a druga - Potockich, w 1995 r. w Łańcucie) ${ }^{105}$. Diana Pelc omówiła Archiwa rodowe z zasobu Centralnego Państwowego Archiwum Historycznego Ukrainy we Lwowie oraz metody ich opracowania; Natalia Cariowa przedstawiła Archiwa podworskie Treterów $i$ Czajkowskich $w$ zbiorach Państwowego Archiwum Historycznego Ukrainy we Lwowie; Ludmiła Zofia Hiscowa i Lidia Andriejewna Suchich zaprezentowały Archiwa $i$ dokumenty rodowe rodów magnackich $i$ szlacheckich prawobrzeżnej Ukrainy $X V-X X$ wieku w zasobie Centralnego Państwowego Archiwum Historycznego Ukrainy w Kijowie - dzieje zbioru, uktad, stan opracowania, perspektywy rozwoju; Galina Anatoliewna Iwanowa scharakteryzowała Archiwa rodowe polskiej i litewskiej szlachty przechowywane w Rosyjskim Państwowym Archiwum Akt Dawnych w Moskwie; oraz Leokadia

104 Reconstruction of the Memory of Poland..., s. 10-11. Apel z 6 marca 1998 r. podpisali profesorowie: Bronisław Geremek (minister spraw zagranicznych), Władysław Bartoszewski (przewodniczący Komisji Spraw Zagranicznych Senatu RP), Andrzej Zakrzewski (przewodniczący Komisji Łączności z Polakami za Granicą Sejmu RP), Jerzy Zdrada (podsekretarz stanu w Ministerstwie Edukacji Narodowej), Aleksander Gieysztor (były prezes Polskiej Akademii Nauk), Henryk Samsonowicz (były rektor Uniwersytetu Warszawskiego i były minister edukacji narodowej), Janusz Tazbir (sekretarz Wydziału I Polskiej Akademii Nauk), Wojciech Wrzesiński (prezes Polskiego Towarzystwa Historycznego), Andrzej Bartnicki (rektor Wyższej Szkoły Nauk Humanistycznych w Pułtusku), Stefan Kuczyński (przewodniczący Rady Archiwalnej przy NDAP), Andrzej Paczkowski (Instytut Studiów Politycznych PAN), Janusz Żarnowski (Instytut Historii PAN) oraz doc. Daria Nałęcz (naczelny dyrektor Archiwów Państwowych). Ibidem, s. 11-13.

105 Referaty wygłoszone na obu konferencjach ukazały się drukiem w wydawnictwie ciagłym AGAD: „Miscellanea historico-archivistica” (w Nieborowie - tom 7, a w Łańcucie - tom 8). 
Olechowicz omówiła Archiwa rodowe w zbiorach Litewskiego Państwowego Archiwum Historycznego ${ }^{106}$.

Białystok był w dniach 20-21 września 1996 r. miejscem obrad ogólnopolskiej konferencji poświęconej polonikom w zasobach archiwów Białorusi, Litwy oraz Obwodu Kaliningradzkiego Federacji Rosyjskiej. Referat wprowadzający pt. Archiwalia polskie $w$ zbiorach naszych wschodnich sqsiadów wygłosił Władysław Stępniak (AGAD) ${ }^{107}$. Natomiast Tadeusz Brzeczkowski (Olsztyn) omówił archiwalia wschodniopruskie z archiwów moskiewskich oraz archiwów i bibliotek wileńskich ${ }^{108}$; Sławomir Filipowicz (Suwałki) scharakteryzował archiwalia dotyczące obszaru Suwalszczyzny w XIX i na początku XX wieku w zasobie Litewskiego Państwowego Archiwum Historycznego w Wilnie ${ }^{109}$; Michał Gnatowski (Białystok) skupił się na materiałach do dziejów Białostocczyzny z lat II wojny światowej przechowywanych w archiwach państwowych Białorusi ${ }^{110}$; Ryszard Masłowski i Jędrzej Tucholski

106 V. Urbaniak, Międzynarodowa konferencja w AGAD poświęcona archiwom rodowym, „Archeion” 1997, t. XCVII, s. 366-367.

107 H. Majecki, Polonika w zasobach archiwów Białorusi, Litwy oraz Obwodu Kaliningradzkiego Federacji Rosyjskiej, „Archeion” 1997, t. XCVIII, s. 314-316; tenże, Wiedza o polonikach i źródłach archiwalnych dotyczacych Polski $w$ zasobie archiwów państwowych Białorusi, Litwy i obwodu kaliningradzkiego Federacji Rosyjskiej, „Białostocczyzna” 1996, nr 3 (43), s. $112-113$.

108 T. Brzeczkowski, Archiwalia wschodniopruskie $w$ archiwach rosyjskich oraz $w$ archiwach i bibliotekach wileńskich, „Białostocczyzna” 1997, nr 1, s. 123-132. Zob. także: J. Jurginis, Das Schicksal der Litauen betreffend Schriften aus Königsberg, „Helmatgruss. Jahrbuch der Deutschen aus Litauen", Leer 1980, s. 119-127; Ekdahl Sven, Archivalien zur Geschichte Ost- und Westpreussen in Wilna, vornehmlich aus den Beständen des Preussischen Staatsarchiv Königsberg, „Mitteilungen der Historischen Kommission für Ost- und Westpreussische Landesforschung und aus Archiven der Stiftung Preussischer Kulturbesitz", Jg. 30, 1992, Bd. 3-4, s. 41-55.

109 S. Filipowicz, Archiwalia $z$ XIX w. dotyczace Suwalszczyzny w zasobie Litewskiego Państwowego Archiwum Historycznego, „Białostocczyzna” 1997, nr 1 (45), s. 150-155; tenże, Źródła do dziejów Suwalszczyzny w archiwach Litwy i Białorusi, „Białostocczyzna" 2000, nr 1 (57), s. 61-66. Zob. także: ks. T. Krahel, Materiały archiwalne do dziejów Kościoła Katolickiego pótnocno-wschodniej Polski w archiwach i bibliotekach Wilna, „Białostocczyzna" 1999, nr 2 (54), s. 38-42; tenże, Archiwa kościelne w archiwach $i$ bibliotekach Wilna, „Białostocczyzna” 1999, nr 3 (55), s. 21-25.

110 M. Gnatowski, Źródła do dziejów Białostocczyzny okresu II wojny światowej w archiwach Republiki Białorusi, „Białostocczyzna” 1993, nr 2 (30), s. 52-56; tenże, Radziecka polityka okupacyjna na Biatostocczyźnie w latach 1939-1941. Zarys tematu i problemy badawcze, w: Spoteczeństwo białoruskie, litewskie i polskie na ziemiach pótnocno-wschodnich II Rzeczypospolitej w latach 1939-1941, pod red. M. Giziejewskiej i T. Strzembosza, Warszawa 1995, s. 110 in. Zob. także: W. Śleszyński, Źródła do dziejów Biatostocczyzny lat 1939-1941 w Państwowym Archiwum Organizacji Społecznych Obwodu Grodzieńskiego $w$ Grodnie, „Białostocczyzna” 1999, nr 2 (54), s. 83-86. 
(Warszawa) ukazali rezultaty poszukiwań w sprawach dotyczących represji przeciwko obywatelom II RP zawartych w dokumentach przechowywanych w archiwach Litwy i Białorusi; Krzysztof Filipow (Białystok) omówił materiały do dziejów wojskowych w zbiorach archiwalnych i pozaarchiwalnych Litwy i Białorusi; Eugenia Szymczuk (Warszawa) ukazała stan poloników w zbiorach Archiwum Narodowego Republiki Białorusi w Mińsku ${ }^{111}$; natomiast białostoccy badacze - Sławomir Iwaniuk, Jan Jerzy Milewski i Zofia Tomczonek - zaprezentowali akta $\mathrm{z}$ okresu międzywojennego przechowywane w Litewskim Centralnym Archiwum Państwowym w Wilnie oraz państwowych archiwach obwodowych Republiki Białorusi w Grodnie i Brześciu ${ }^{112}$.

Pod hasłem Polonika $w$ archiwach Litwy, Łotwy i Biatorusi w dniach 19-20 czerwca 1997 r. obradowała w Białymstoku międzynarodowa konferencja archiwistów. Podczas obrad zaprezentowano wydawnictwo pt. Informator o archiwaliach kresów pótnocno-wschodnich Drugiej Rzeczypospolitej w zasobach archiwów biatoruskich i LCVA w Wilnie (Białystok 1996). W obradach uczestniczyli także goście zagraniczni: Ēriks Jēkabsons z Państwowego Archiwum Historycznego Łotwy w Rydze ${ }^{113}$, Inga Bumażnikowa z Centralnego Archiwum Państwowego Litwy w Wilnie, Rimantas Miknys z Instytutu Historii Litwy w Wilnie oraz dyrektorzy archiwów obwodowych Republiki Białorusi: Anna W. Terebuń (Brześć) i S. A. Kondraszowa (Grodno). Omówili oni materiały dotyczące Polski i Polaków z archiwów Łotwy, Litwy i Białorusi ${ }^{114}$.

111 E. Szymczuk, Materiaty do najnowszych dziejów Polski w państwowych archiwach białoruskich w Minsku, „Białostocczyzna” 1997, nr 2 (46), s. 62-67.

112 Zob. S. Iwaniuk, Materiaty do dziejów Polski okresu międzywojennego w zbiorach Państwowego Archiwum Obwodu Brzeskiego, „Białostocczyzna” 1992, nr 2 (946), s. 68-70; Z. Tomczonek, Źródła do dziejów kresów północno-wschodnich Drugiej Rzeczypospolitej w zbiorach Litewskiego Centralnego Archiwum Państwowego w Wilnie, "Białostocczyzna” 1997, nr 4 (48), s. 98-104.

$113 \overline{\mathrm{E}}$. Jēkabsons, Materiaty o internowanych polskich zotnierzach na Eotwie 1939-1940 w państwowym Archiwum Historycznym Eotwy, „Białostocczyzna” 1999, nr 2 (54), s. $77-82$.

114 H. Majecki, Trzecia konferencja archiwalna w Białymstoku poświęcona polonikom na Litwie, Eotwie i Białorusi, „Archeion” 1997, t. XCVIII, s. 313-314; B. Woszczyński, Polonika w archiwach północno-wschodnich sasiadów, „Archiwista Polski” 1997, R. II, nr 4, s. 67-70. Zob. Miknys Rimantas, Źródta do historii politycznej dawnej Rzeczypospolitej w spuściźnie Towarzystwa Przyjaciót Nauk w Wilnie, „Białostocczyzna” 1997, nr 4 (48), s. 83-90; tenże, Spuścizna Ludwika Abramowicza, Heleny Romer-Ochenkowskiej i Michata Romera w Bibliotece Akademii Nauk Litwy jako źródto do dziejów bytego Wielkiego Księstwa Litewskiego i wschodnich obszarów Korony, „Białostocczyzna” 1998, nr 4 (52), 
W dniach 20-22 października 1997 r. w Nieborowie odbyła się, zorganizowana przez AGAD, międzynarodowa konferencja naukowa pt. Księgi sqdowe z obszaru I Rzeczypospolitej jako źródto do dziejów wielonarodowościowego państwa do $1795 \mathrm{r}$. Uczestniczyli w niej z referatami także archiwiści i historycy z Ukrainy. Wiktoria L. Babkina (Kijów) mówiła o kolekcjach ksiąg ziemskich Centralnego Państwowego Archiwum Ukrainy w Kijowie; Wiktor W. Straszko (Kijów) scharakteryzował zawartość ksiąg sądowych w Centralnym Państwowym Archiwum Ukrainy w Kijowie; Natalia Cariowa (Lwów) scharakteryzowała księgi sądowe w zasobie Archiwum Historycznego Ukrainy we Lwowie; a Oleg Kupchynskij (Lwów) omówił księgi grodzkie i ziemskie województwa ruskiego XV-XVIII w. Jak pisze Violetta Urbaniak: „wszystkie założone cele konferencji zostały zrealizowane, a oto najważniejsze $z$ nich: 1. Uzyskanie informacji odnośnie do rodzajów serii, ram chronologicznych, merytorycznej treści wpisów, objętości ksiąg dawnych województw: kijowskiego, wołyńskiego, podolskiego, bracławskiego, ruskiego [...]. 2. Uzyskanie informacji o poziomie i metodach opracowania akt sądów ziemskiego i grodzkiego oraz dostępnych pomocy archiwalnych [...]. Wypada przy tym wyrazić ubolewanie, że nie przyjechali na obrady przedstawiciele archiwów Białorusi, pomimo deklarowanego wpierw zainteresowania przygotowywaną problematyką" ${ }^{115}$.

Z kolei AP w Białymstoku (wspólnie z Politechniką, Uniwersytetem i Białostockim Towarzystwem Naukowym) zorganizowało w Białymstoku w dniach 18-19 czerwca 1998 r. konferencję międzynarodową pt. Polonika $w$ archiwach, bibliotekach $i$ muzeach Biatorusi, Litwy $i$ Łotwy, podczas której omówiono m.in.: międzynarodową współpracę archiwalną oraz badania poloników w zbiorach północno-wschodnich sąsiadów Polski (Władysław Stępniak z Warszawy), losy archiwów grodzieńskich w XV-XVIII w. (Jurij Gorgiew z Grodna), badania nad problematyką rodów szlacheckich polskiego pochodzenia na Nowogródczyźnie (Zmicier Jackiewicz z Mińska), źródła do dziejów kościoła i klasztoru oo. Dominikanów w Stopcach (Hryhory

s. 41-45; E. Jēkabsons, Materiaty dotyczace stosunków totewsko-polskich i mniejszości polskiej na Eotwie w Państwowym Archiwum Historycznym Eotwy, „Białostocczyzna” 1997, nr 4 (48), s. 91-97; A. Terebuń, Źródła do historii południowo-wschodniej części Białostocczyzny w latach 1939-1941 w zasobie Archiwum Państwowego Obwodu Brzeskiego, „Białostocczyzna” 1998, nr 4 (52), s. 65-68.

115 V. Urbaniak, Międzynarodowa konferencja „Księgi sadowe z obszaru I Rzeczypospolitej jako źródto do dziejów wielonarodowościowego państwa do 1795 r.", "Archeion" 1998, t. XCIX, s. 355-356. 
Žauniarkiewicz z Mińska), stan źródeł do polskich powstań XIX w. przechowywanych w archiwach państwowych Grodna i Mińska (Wiaczesław Szwed z Grodna), zbiory rękopiśmienne Wincentego Mienickiego w Siemigorach w zasobie Białoruskiego Muzeum Państwowego w Mińsku (Iryna Bohdanowicz z Mińska), zbiory Litewskiego Państwowego Archiwum Historycznego dotyczące weryfikacji szlachectwa w XIX w. (Tamara Bairašauskaitè z Wilna) ${ }^{116}$, materiały dotyczące Polski w zbiorach bibliotek i muzeów Łotwy (Ēriks Jēkabsons z Rygi) ${ }^{117}$, akta radziwiłłowskie w zasobie Archiwum Narodowego Republiki Białorusi w Mińsku (Elżbieta Bagińska z Białegostoku) ${ }^{118}$, akta obozu odosobnienia w Berezie Kartuskiej z lat 1934-1939 w zasobie Archiwum Obwodowego w Brześciu (Tamara Kabot z Brześcia) ${ }^{119}$, źródła do dziejów miast i miasteczek kresów północno-wschodnich II Rzeczypospolitej w archiwach litewskich i białoruskich (Jan Jerzy Milewski z Białegostoku) ${ }^{120}$.

W roku następnym ośrodek białostocki zorganizował w dniach 9 i 10 września konferencję nt. Kresy pótnocno-wschodnie dawnej Rzeczypospolitej - źródta $i$ stan badań, w której uczestniczyli referenci zagraniczni: Tamara Bairašauskaitè (Wilno), Ēriks Jēkabsons (Ryga), Iryna Bohdanowicz (Mińsk), Ryhor Żaūniarkiewicz (Mińsk), Anna Terebuń (Brześć), Jury Hardziejeu (Brześć) i Edmund Jarmusik (Brześć). Scharakteryzowali oni zasoby archiwów i bibliotek na Białorusi i Litwie oraz w Estonii ${ }^{121}$.

116 T. Bairašauskaitè, Materiaty do dziejów Białostockiego Instytutu Dobrze Urodzonych Panien w zbiorach Litewskiego Państwowego Archiwum Historycznego w Wilnie, „Białostocczyzna”. 2000, nr 1 (57), s. 13-20. Zob.: taż, Zbiory Litewskiego Państwowego Archiwum Historycznego dotyczace weryfikacji szlachectwa w XIX w., „Białostocczyzna” 1998, nr 4 (52), s. 51-57; ta ż, Dzienniki szlachty litewskiej z XIX wieku w zbiorach wileńskich, „Białostocczyzna” 1999, nr 2 (54), s. 32-37.

117 E. Jēkabsons, Materiaty dotyczace Polski w zbiorach muzeów Eotwy, „Białostocczyzna" 1998, nr 4 (52), s. 103-106; tenże, Wydawnictwa i prasa polska na Eotwie w latach 1918-1940, „Białostocczyzna” 2000, nr 3-4 (59-60), s. 79-88. Zob. także: J. Albin, Polski ruch narodowy na Eotwie w latach 1919-1940, Wrocław 1993.

118 E. Bagińska, Źródta do dziejów Radziwittów w archiwach i bibliotekach wileńskich, „Białostocczyzna” 1997, nr 4 (48), s. 68-78.

119 T. Kabot, Akta Miejsca Odosobnienia w Berezie Kartuskiej (1934-1939) jako źródto historyczne, „Białostocczyzna” 1998, nr 4 (52), s. 58-64.

120 B. Parafiniuk, Konferencja naukowa „Polonika w archiwach, bibliotekach i muzeach Biatorusi, Litwy i Eotwy”, „Archeion” 1999, t. C, s. 436-437.

121 B. Parafiniuk, Konferencja naukowa „Kresy pótnocno-wschodnie dawnej Rzeczypospolitej - źródta i stan badań, „Archeion” 2000, t. CI, s. 296-298. 
Ponadto NDAP zorganizowała konferencje pod auspicjami Międzynarodowej Rady Archiwów z udziałem archiwistów z państw Europy Środkowowschodniej dotyczące: 1) Archiwów popartyjnych w Europie Środkowowschodniej (w dniach 28 września - 1 października 1995 r. w Starej Wsi pod Węgrowem) ${ }^{122}$, 2) Archiwa Europy Środkowowschodniej $w$ dobie przeksztatceń prawnoustrojowych (w dniach 28-30 czerwca 1996 r. w Puławach) ${ }^{123}$, 3) Wspólne dziedzictwo archiwalne krajów $i$ narodów centralnej $i$ wschodniej Europy (w dniach 22-24 października 1997 r. w Goławicach pod Warszawą) ${ }^{124}$, 4) Archiwa prywatne $i$ archiwalia prywatne $w$ krajach Europy Środkowej $i$ Wschodniej (w dniach 8-10 października 1998 r. w Mądralinie k. Warszawy) ${ }^{125}$; 5) Udostępnianie archiwaliów $w$ świetle prawa i praktyki Europy Środkowej $i$ Wschodniej (w dniach 15-16 października 1999 r. w Mądralinie k. Warszawy) ${ }^{126}$. Dla uczczenia pamięci inicjatora tego cyklu spotkań archiwistów z państw Europy Środkowej i Wschodniej, tragicznie zmarłego latem 1996 r. prof. Jerzego Skowronka - naczelnego dyrektora Archiwów Państwowych RP - nadano im nazwę Colloquia Jerzy Skowronek dedicata ${ }^{127}$.

Fundacja Stefana Batorego była w styczniu 2002 r. organizatorem międzynarodowej konferencji nt. Przemieszczone dobra kultury. Przypadek Europy Zachodniej $i$ problemy państw Europy Środkowej $i$ Wschod-

122 Archiwa bytych partii komunistycznych krajów Europy Środkowej $i$ Wschodniej, „Archeion” 1996, t. XCVI, s. 26-37; E. Rosowska, Międzynarodowa konferencja naukowa archiwistów krajów Wschodniej i Środkowej Europy, „Archiwista Polski” 1996, R. I, nr 1, s. 82-90. Materiały ogłoszono drukiem: Sbornik materiałow po miezdunarodnoj konferencji "Archiwy bywszych komunisticzeskich partii w stranach centralnoj i wostocznoj Jewropy", pod red. J. Skowronka, Warszawa 1996.

123 E. Rosowska, Przeksztatcenia w zakresie prawa..., s. 51-57; B. Woszczyński, Międzynarodowa konferencja archiwalna w Puławach, „Archeion” 1997, t. XCVII, s. 348-353. Materiały ogłoszono drukiem: Archiwa Europy Środkowej $i$ Wschodniej w dobie przeksztatceń prawnoustrojowych, pod red. B. Woszczyńskiego, Warszawa 1997.

124 B. Woszczyński, Problemy dziedzictwa archiwalnego, „Archiwista Polski” 1998, R. III, nr 1 (9), s. 78-82; E. Rosowska, Problemy dziedzictwa archiwalnego, "Archeion" 1998, t. XCIX, s. 351-354. Materiały ogłoszono drukiem: The Common Archival Heritage of States and Nations of Central and Eastern Europe, pod red. W. Stępniaka, Warszawa 1998.

125 B. Woszczyński, IV Międzynarodowa Konferencja poświęcona archiwaliom prywatnym, „Archeion” 1999, t. C, s. 415-417.

126 E. Rosowska, V Międzynarodowa Konferencja „Udostępnianie archiwaliów w świetle prawa i praktyki Europy Srodkowej $i$ Wschodniej, "Archeion” 2000, t. CI, s. 277-279.

127 W. Stępniak, "Colloquia Jerzy Skowronek dedicata” we wspótpracy archiwów państw Europy Środkowej i Wschodniej, „Archeion” 1999, t. C, s. 123-129; tenże, Problemy udostępniania archiwaliów w państwach Europy Środkowej $i$ Wschodniej, „Archiwista Polski" 2000, R. V, nr 2 (18), s. 57-67. 
niej $w X X$ wieku. Stronę niemiecką reprezentował redaktor Jürgen Vietig z "Deutsche Welle” w Berlinie, rosyjską - redaktor Olga Kabanowa z „Izwiestii” w Moskwie, litewską - prof. Zigismuntas Kiaupa z Wilna, a polską - dr Roman Wóycicki (dyrektor Instytutu Polskiego w Lipsku) oraz prof. Krzysztof Pomian ${ }^{128}$, który wygłosił referat wprowadzający pt. Dobra kultury, skarby narodowe, restytucja ${ }^{129}$.

Zabiegi o restytucję dóbr kultury (w tym głównie archiwaliów) poprzez ich repartycję (odpisy) dokonują się przede wszystkim w oparciu o umowy między Naczelną Dyrekcją Archiwów Państwowych w Warszawie a dyrekcjami archiwów poszczególnych państw. W okresie Trzeciej Rzeczypospolitej podpisano, obok omówionych już w tym rozdziale porozumień archiwalnych z Białorusią, Litwą i Ukrainą, także umowy z Łotwą, Rosją oraz archiwami RFN.

Natomiast Biuro Pełnomocnika Rządu ds. Polskiego Dziedzictwa Kulturalnego za Granicą współpracuje blisko z Międzynarodową Fundacją ds. Poszukiwania Dzieł Sztuki (IFAR), która prowadzi od 1991 r. Rejestr utraconych dziet sztuki (The Art Loss Registry - ALR), będący komputerową, międzynarodową bazą danych, zawierającą informacje o skradzionych i zaginionych dziełach sztuki. ALR posiada trzy biura: w Londynie, Nowym Jorku i West Perth w Australii. Fundacja wydaje miesięcznik „IFAR Report", natomiast ALR ogłasza roczne sprawozdania oraz wydaje kwartalnik „ALR - News”, w których prezentowane są najcenniejsze przypadki odnalezienia utraconych dzieł sztuki ${ }^{130}$. Osobne zainteresowanie Biura skupiaja zabytki polskie znajdujące się za wschodnią granicą Polski (głównie na terytorium Litwy, Białorusi i Ukrainy). Zbieranie o nich informacji ma charakter wieloetapowy. Przekłada się ono na: a) kwerendy archiwalne, biblioteczne i ikonograficzne, b) prace inwentaryzacyjne w terenie, c) materiały pozyskiwane dzięki współpracy z osobami prywatnymi i instytucjami w kraju i za granicą ${ }^{131}$. Temu zagadnieniu poświęcona była międzynarodowa konferencja naukowa we Lwowie w dniach 12-14 listopada 1998 r. zatytułowana: Ostatnie dziesięć lat badań historyków sztuki nad zabytkami Ukrainy, Biatorusi

128 C. Polak, Niech przemówia prawa. Dyskusja o przemieszczeniu dóbr kultury jest dyskusja o pojednaniu, „Gazeta Wyborcza”, nr 23 (3931) z 28 stycznia 2002, s. 16.

129 Skrócony tekst referatu ukazał się drukiem: K. Pomian, Prawdziwy koniec wielkiej wojny, „Gazeta Wyborcza”, nr 138 (4046) z 15-16 czerwca 2002, s. 14-15.

130 P. Ogrodzki, The Art Loss Registry (ALR), "Cenne - Bezcenne - Utracone”, nr 2, kwiecień 1997, s. 18.

131 Dziatalność Biura Petnomocnika Rzadu ds. Polskiego Dziedzictwa Kulturalnego za Granıca, „Cenne - Bezcenne - Utracone”, nr 3, czerwiec 1997, s. 27. 
i Litwy, której współprzewodniczyli prof. Andrij Rudnickyj z Politechniki Lwowskiej i prof. Jerzy Kowalczyk z Instytutu Sztuki PAN. Łącznie wygłoszono 30 referatów ${ }^{132}$.

\section{Zakończenie}

Wieloletnie doświadczenia w poszukiwaniu polskich dóbr kultury wykazały, iż istnieja obok siebie dwa odmienne sposoby traktowania zagrabionych w przeszłości dóbr kultury przez ich obecnych posiadaczy. Janusz Tazbir nazwał pierwszy z nich szwedzkim, a drugi radzieckim. Różnica między nimi polega na tym, że: „Sposób szwedzki polega na sporządzaniu dokładnych katalogów, dzięki którym można bez trudu dotrzeć do poszukiwanego dokumentu czy książki. Radziecki sprowadzał się do trzymania tych zbiorów pod kluczem przy równoczesnym baczeniu, aby ich dawni właściciele nie dowiedzieli się o istnieniu danej pozycji" 133 .

Dwoistość postępowania grabieżców z polskimi dobrami kultury - gdzie sposób szwedzki realizowała jedynie Szwecja, a radziecki wszystkie pozostałe kraje - zmusiła Polskę przy próbach ich restytucji do stosowania kilku sposobów umożliwiających wzbogacenie dóbr kultury narodowej, czyli: rewindykację, rewindykację wymienną, windykację, reewakuację, repartycję i repatriację.

Prowadzone przez Polskę tymi sposobami działania na rzecz restytucji polskich dóbr kultury pozwalają na sformułowanie - jako rezultatu prowadzonych badań i analiz - kilku wniosków porównawczych i uogólniających:

1. Polska Ludowa już w 1945 r. podjęła starania o rewindykację i reewakuację polskich dóbr kultury ze stref okupacyjnych Niemiec i Austrii, co zakończyło się częściowym powodzeniem w zachodnich strefach okupacyjnych. Z radzieckiej strefy okupacyjnej pojechały w przytłaczającej większości do ZSRR, gdyż nie była ona państwem suwerennym, lecz satelitą Moskwy (choć wystąpiły także pojedyncze przypadki wymiany akt $\mathrm{z}$ terenu ziem zachodnich między Polską a radziecką strefą okupacyjną). Wówczas alianci zachodni uznali prawo Niemców do posiadania wywiezionych ze wschodu dóbr kultury.

132 J. Miler, Prace dokumentacyjne na Wschodzie, "Cenne - Bezcenne - Utracone", nr 6 (12), grudzień 1998, s. 3-5.

133 J. Tazbir, Pamięć w kawatkach. Polska skopiuje to co jej zabrano, „Polityka”, nr 23 (2301) z 9 czerwca 2001, s. 78. 
2. Działania restytucyjne władz PRL po 1956 r. nie były typową rewindykacją, lecz w przypadku ZSRR - aktem łaski lub „darem” (chociaż była także ograniczona wymiana).

3. Dopiero suwerenna Trzecia Rzeczpospolita - w oparciu o układy o dobrym sąsiedztwie i przyjaznej współpracy z Ukrainą i Białorusią (1992) oraz z Litwą (1994) - podjęła starania o restytucję wywiezionych w okresie zaborów oraz w czasie I i II wojny światowej polskich dóbr kultury, znajdu jących się obecnie na terytorium tych państw.

Stawiając jednak pytanie: „co zwracać?”, a „czego żądać?” - należy pamiętać o obowiązujących normach prawa międzynarodowego (szczególnie że będąc stowarzyszeni z Unią Europejską, staramy się wejść do zjednoczonej w Unii Europejskiej części naszego kontynentu). Obecnie powszechnie respektowana jest zasada pertynencji ograniczonej, która dobra kultury przypisuje do obszaru ich powstania, a wraz ze zmianą granic, ulega zmianie także ich właściciel; a prawo restytucji (głównie poprzez wykonanie kopii czyli prawo repartycji) odnosi się jedynie w odniesieniu do akt o charakterze administracyjnym. Stąd np. polskie roszczenia wobec Ukrainy o zwrot wielu poloników (zwłaszcza lwowskich) - choć uzasadnione historycznie i emocjonalnie - pod względem prawnym nie są jednak bezdyskusyjne (gdyż państwem sukcesorem jest Ukraina, a państwem poprzednikiem - Polska). Podobnie jak i Republika Federalna Niemiec nie posiada prawnych podstaw by rościć pretensje do cennej Biblioteki Uniwersyteckiej we Wrocławiu (tutaj państwem sukcesorem jest Polska, a państwem poprzednikiem - RFN). Sytuacja obydwu państw - Polski i Niemiec - nie jest jednak analogiczna. Jak konstatuje Wojciech Kowalski:

„Decyzją Aliantów Polska utraciła 1/3 swego terytorium na wschodzie na rzecz trzech sąsiadujących z nią republik radzieckich: Litwy, Białorusi i Ukrainy, a jednocześnie uzyskała poważny przyrost terytorialny na zachodzie kosztem Niemiec. W obydwu przypadkach cesja terytorialna objęła również niemal całe dziedzictwo kulturowe przekazywanych ziem, pozostawiając sprawę ewentualnych repatriacji późniejszym uzgodnieniom dwustronnym. Z jednej więc strony Polska utraciła swe wielowiekowe dziedzictwo na wschodzie, z drugiej zaś wzbogaciła się o równie historyczną spuściznę niemiecką na zachodzie. Trzeba tu jeszcze wskazać na istotną różnicę, jaka zachodziła pomiędzy omawianymi zmianami terytorialnymi, a wszystkimi niemal cesjami wcześniejszymi. Zmieniła ona bowiem także »kierunek « postulowanej repatriacji. Otóż zmiany graniczne po drugiej wojnie światowej pociągnęły za soba przesiedlenie ogromnej liczby mieszkańców - Niemców na zachód Niemiec, a Polaków ze wschodu do Polski. W obydwu przypadkach dziedzictwo przekazane wraz z terytorium znalazło się w obcym mu kulturowo państwie, pozbawione swych naturalnych odbiorców, właścicieli i opiekunów. W konsekwen- 
cji zrodziło to ze strony polskiej żądania przeniesienia tego dziedzictwa w ślad za ludnością na nowe miejsce ich osiedlenia. Przejęte wraz z byłym terytorium niemieckim dobra kultury niemieckiej zostały praktycznie w całości znacjonalizowane przez władze polskie w latach $1945-1946^{134}$, przy czym rządy zarówno byłej Niemieckiej Republiki Demokratycznej jak i Republiki Federalnej [Niemiec] nigdy się o nie oficjalnie nie upomniały. Powodem były najpewniej ogromne zniszczenia kultury polskiej spowodowane okupacją hitlerowską w Polsce" ${ }^{135}$.

Odmienne stanowisko zajmuje Władysław Stępniak, pisząc, iż mimo że:

„Polska jest ofiarą przemocy państw sąsiednich, to występu je na arenie międzynarodowej w innym charakterze, niż miało to miejsce po I wojnie światowej. Występowała bowiem wtedy wyłącznie w charakterze państwa - sukcesora. Od roku 1945 jest natomiast państwem - sukcesorem w odniesieniu do zachodniej i północnej części jej obecnego terytorium oraz państwem - poprzednikiem w odniesieniu do tych części jej b. terytorium, które przejęły Litwa, Białoruś i Ukraina. Wynika z tego, że roszczenia, jakie wysunąc możemy pod adresem naszych wschodnich sąsiadów w związku z przejęciem przez nich archiwów na b. terenach wschodnich Rzeczypospolitej - a były to archiwa duże i obfitujące w ważne dla historii Polski materiały - moga być wysunięte $\mathrm{w}$ stosunku do nas ze strony Niemiec w związku z przejęciem przez nas - także dużych i zawierających ważne materiały - b. archiwów niemieckich na nowych terenach" ${ }^{136}$.

A także:

„Nie wymaga wyjaśnienia prawo Polski do restytucji, w tym i restytucji zastępczej, mienia wywiezionego przez okupanta radzieckiego i wojska sowieckie z jej obecnego terytorium. Zasada »Quod is in territorio, es etiam de territorio « oznacza w odniesieniu do naszych rozważań, że własność państwa dzieli całkowicie los terytorium, a więc przechodzi na sukcesora. To zastrzeżenie dotyczy oczywiście obecnej zachodniej i północnej części terytorium RP oraz b. ziem wschodnich. [...] W wyniku

134 Podstawa prawną konfiskat były: 1) dekret z 2 marca 1945 r. o majątkach opuszczonych i porzuconych (DzU RP, 1945, nr 9, poz. 45); 2) ustawa z 6 maja 1945 r. o wyłączeniu ze społeczeństwa polskiego wrogich elementów (DzU RP, 1945, nr 17, poz. 96); 3) dekret z 8 marca 1946 r. o majatkach opuszczonych i poniemieckich (DzU RP, 1946, nr 12, poz. 87); 4) dekret z 28 czerwca 1946 r. o odpowiedzialności karnej za odstępstwo od narodowości polskiej w czasie wojny (DzU RP, 1946, nr 41, poz. 237 i nr 53, poz. 300); 5) dekret z 13 września 1946 r. o wyłączeniu ze społeczeństwa polskiego osób narodowości niemieckiej (DzU RP, 1946, nr 55, poz. 310), nieco zmieniony dekretem z 28 października 1947 r. o tej samej nazwie (DzU RP, 1947, nr 66, poz. 404). Zob. szerzej: D. Matelski, Niemcy w Polsce $w$ XX wieku..., s. 243-246 i 249-250.

135 W. Kowalski, Repatriacja dóbr kultury..., s. 22-23; tenże, Repatriation of Cultural Property following a Cession of Territory or Dissolution of Multinational States, „Art, Antiquity and Lawk" 2001, Vol. VI. Issue 2.

136 W. Stępniak, Żadania rewindykacyjne..., s. 32. 
zmiany granicy państwowej archiwalia dzielą los swej siedziby, a ich posiadaczem staje się państwo, do którego ta siedziba należy. Wówczas gdy w skład zasobu danego archiwum wchodzą zespoły archiwalne dotyczące terenów po. jednej stronie granicy, stają się one własnością państwa, które posiada te tereny. Zespoły dotyczące terenów po obu stronach granicy są w posiadaniu państwa, na którego terytorium znajduje się siedziba archiwum. W wypadku jednak, gdy w większym stopniu dotyczą one terytorium państwa - poprzednika, zostaną mu wydane. Uzupełnieniem tych regulacji są zasady udostępniania materiałów archiwalnych w związku z sukcesja państw. Sprowadzają się one głównie do wymiany mikrofilmów interesujących strony akt, których oryginały nie podlegają przekazaniu. W sytuacji, gdy realizacja wyżej przedstawionych zasad, w określonych przypadkach, natrafić może na poważne trudności, możliwe jest zastosowanie, w charakterze środka specjalnego, propagowanej przez UNESCO koncepcji tzw. wspólnego dziedzictwa kulturalnego" 137.

Tak więc na niekorzyść Polski w sprawach restytucyjnych wpływa obecnie fakt przesunięcia granic naszego państwa w kierunku zachodnim po II wojnie światowej. Jednak należy pamiętać, że prawo międzynarodowe publiczne rozróżnia postępowanie wobec mienia państwowego (tu zasada przejścia praw na sukcesora nie powinna podlegać dyskusji) i mienia niepaństwowego. Biblioteka im. Ossolińskich to właśnie mienie niepaństwowe, w którego przypadku ważna jest wola właściciela (zapis notarialny), czy też jego prawnego następcy. Na to właśnie Polska powołuje się w sporze z Ukrainą.

Powodzenie polskich starań restytucyjnych zależeć będzie więc od wypracowania modus vivendi zarówno wobec sąsiada na granicy zachodniej, jak i sąsiadów na jej rubieżach północno-wschodnich i południowych.

137 W. Stępniak, Archiwalia polskie w zbiorach państw obcych, w: Archiwa polskie wobec wyzwań..., s. 53-54. 